\title{
Essay
}

\section{Copy This Essay: How Fair Use Doctrine Harms Free Speech and How Copying Serves It}

\author{
Rebecca Tushnet ${ }^{\dagger}$
}

\section{CONTENTS}

INTRODUCTION.

I. OVERVIEW: THE FIRST AMENDMENT, COPYRIGHT, AND THE CONFLICT BETWEEN THEM

A. What Free Speech Is For ..................................................... 538

B. Copyright and Fair Use .......................................................... 540

C. The First Amendment Value of Copying .................................... 545

II. LIMITING THE FIRST AMENDMENT BY INVOKING FAIR USE

A. How the First Amendment Value of Dissent Maps onto Transformative Fair Use

B. How the Identification of Transformative Use with the First Amendment Obscures Other Free Speech Values....

$\dagger$ Assistant Professor, NYU School of Law; Visiting Associate Professor, Georgetown University Law Center, 2004-2005. Thanks to participants in the NYU Brown Bag Lunch series, the Brooklyn Law School Faculty Workshop, the Georgetown Advanced Constitutional Law Seminar, the Virginia Intellectual Property Colloquium, Amy Adler, Jack Balkin, Rachel Barkow, Lillian BeVier, Julie Cohen, Francesca Coppa, Jeffrey Cunard, Rochelle Dreyfuss, Harry First, Laura Heymann, Larry Kramer, Larry Lessig, Neil Netanel, Richard Primus, Kermit Roosevelt, Zach Schrag, Eugene Volokh, Tim Wu, and Diane Zimmerman for comments. As always, special thanks to Mark Tushnet, for just the right amount of advice. 
1. Copyright's Other Speech-Protective Limits. 553

2. The Redefinition of Fair Use To Suppress Unauthorized Copying 555

C. Is It the First Amendment's Fault? 560

III. THe VAlue of PuRe COPYING 562

A. Copying's Value to the Audience ................................................565



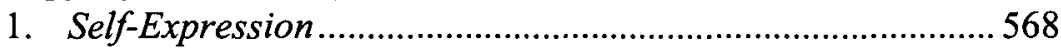



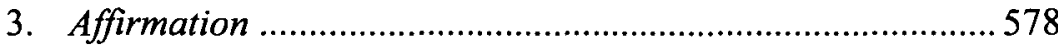

C. Copyright's Real-World Suppressive Effects ............................582

IV. CODA: SOME SPECULATION ABOUT COPYRIGHT'S EFFECTS ON THE FIRST AMENDMENT . 


\section{INTRODUCTION}

What is copying good for? Why would someone of good faith want to copy? Debates over massive file sharing of music and movies have helped to make "copier" a synonym for "pirate." At the same time, many people, particularly in the academy, have expressed concern about the use of copyright to suppress critical and creative- "transformative," in copyright's terms-uses of copyrighted works, such as a retelling of Gone with the Wind from the perspective of an invented mulatto character. Defenders of transformative uses have invoked the First Amendment to bolster claims that such uses should not be subject to the copyright owner's permission. But this focus on transformation is critically incomplete, leaving unchallenged much of copyright's scope, despite the large number of nontransformative copying activities that are also instances of free speech. The current debate leaves the way open for expansions of copyright that, while not targeted at dissenting viewpoints, nonetheless may have a profoundly negative effect on freedom of speech. In other words, transformation has limited our thinking about the free speech interests implicated by copying. As fair use has grown in doctrinal importance as a means to harmonize copyright with the First Amendment, it has also, paradoxically, begun to shrink, excluding activities such as copying for research or educational purposes. Courts increasingly find that these traditional fair uses, which do not directly involve critical commentary, are unfair and require the copyright owner's permission. Using fair use and free speech as interchangeable concepts thus has a profound and negative narrowing effect on the scope of fair use and in turn threatens First Amendment freedoms, because noncritical uses of copyrighted works have substantial value to society and to freedom of speech.

The purpose of this Essay is not to propose a solution to the conflict between protecting copyright owners' rights and allowing freedom of speech. Indeed, I do not believe that such a solution is possible, because copying may sometimes be an instance of free speech even when it is also copyright infringement. Tradeoffs are inevitable, and although there are better and worse ways of balancing the interests at stake, my main aim in this Essay is to explain what copying is good for rather than to define the ideal scope of the rights granted by copyright. 


\section{OVERVIEW: THE FIRST AMENDMENT, COPYRIGHT, AND THE CONFLICT BETWEEN THEM}

\section{A. What Free Speech Is For}

I wish to make what I hope is a rather modest claim: The current version of copyright, in which free speech problems are solved by keeping copyright owners from controlling certain transformative uses but in which more ordinary unauthorized copying is prohibited, is incompatible with the First Amendment. This is true whether one understands the First Amendment as protecting political speech, promoting democracy or selfgovernment, furthering the search for truth, or enhancing autonomy and enabling self-expression.

These descriptions are necessarily incomplete. Most important, my discussion does not address the First Amendment as a purely negative right, protecting speakers from government action based on their speech. Yet if the First Amendment bars only government action, then copyright law itself ought to be unconstitutional as a government restriction on some speakers in order to improve the relative position of others. ${ }^{1}$

Rather than defend a particular view of the First Amendment, I hope to offer examples in which copyright law conflicts with free speech as it is understood by a variety of theories. Most obviously, I defend copying as a method of self-expression and self-definition consistent with autonomybased accounts of freedom of speech. My argument also often refers to copying in service of democratic self-governance, which is the purpose of free speech identified by many current theorists of copyright and the First Amendment, including Jack Balkin, Yochai Benkler, and Neil Netanel.

1. See Rebecca Tushnet, Copyright as a Model for Free Speech Law: What Copyright Has in Common with Anti-Pornography Laws, Campaign Finance Reform, and Telecommunications Regulation, 42 B.C. L. REV. 1, 3 (2000). A related argument is that the First Amendment is mostly concerned with specific kinds of government action, to wit, censorious government action. See Christopher L. Eisgruber, Censorship, Copyright, and Free Speech: Some Tentative Skepticism About the Campaign To Impose First Amendment Restrictions on Copyright Law, 2 J. ON TELECOMM. \& HIGH TECH. L. 17 (2003). Like libel law, however, copyright law allows private parties to enlist the machinery of government-judges, juries, and federal marshals-to silence speech and speakers, and this distorts public discourse in predictable ways, which is what we often mean by "censorship." See Brief of Amici Curiae College Art Association et al. at 8-9, 18, Eldred v. Ashcroft, 537 U.S. 186 (2003) (No. 01-618); Tushnet, supra, at 22, 27.

2. See, e.g., Jack M. Balkin, Digital Speech and Democratic Culture: A Theory of Freedom of Expression for the Information Society, 79 N.Y.U. L. REV. 1 (2004) (arguing that freedom of speech pronotes a "democratic culture"); Yochai Benkler, Through the Looking Glass: Alice and the Constitutional Foundations of the Public Domain, LAW \& CONTEMP. PROBS., Winter/Spring 2003, at 173; Neil Weinstock Netanel, Copyright and a Democratic Civil Society, 106 YALE L.J. 283 (1996); see also Shubha Ghosh, Copyright as Privatization: The Case of Model Codes, 78 TUL. L. REV. 653, 663, 663-68 (2004) (arguing that "the theory of democratic governance grounds copyright and cultural production in the twin values of autonomy and participation" and 
Briefly, democratic self-governance builds on Alexander Meiklejohn's classic defense of the First Amendment as guarantor of democracy. ${ }^{3}$ His definition of democracy, however, meant that only political speech-speech about government and what it should or shouldn't be doing-was protected from suppression. ${ }^{4}$ His theory famously had trouble explaining why art and literature should be protected, except as poor stepchildren of political speech. Meiklejohn was also more concerned with speech than with speakers; as long as everything worth saying got said, it didn't matter whether everyone had a chance to speak. ${ }^{5}$ In the Meiklejohnian tradition, the autonomy component of free speech is less important than its instrumental component-individual speech deserves protection only to further the goal of enriching public debate. ${ }^{6}$

Theorists after Meiklejohn have expanded the concept of free speech's role in preserving democracy in two major ways. First, participation in public discussion is important, both to the individual and to the society that values each individual. ${ }^{7}$ Second, democracy requires more than democratically elected rulers; it requires democratic culture. Popular culture is worth the First Amendment's protection not only, and not mostly, because it indirectly affects political attitudes but because it constitutes a major part of modern citizens' environment, shaping how we think and act. ${ }^{8}$ Our lives are lived with the constant intrusion of multiple media productions, and many of our interactions with other people involve what we've been watching, listening to, or even reading. Encounters with explicitly political content are much more infrequent and much less central

discussing how to create institutions to implement these values (emphasis omitted)). But cf. Jed Rubenfeld, The Freedom of Imagination: Copyright's Constitutionality, 112 YALE L.J. 1 (2002) (basing criticism and defense of copyright on a theory of free speech that makes the "freedom of imagination" central).

3. See AleXander Meiklejohn, Free Speech and Its Relation to SElf-Government (1948).

4. Id. at 93-94.

5. Alexander Meiklejohn, Political Freedom: The Constitutional PoWers of the PEOPLE 26 (1960).

6. See, e.g., Owen M. Fiss, Why the State?, 100 HARV. L. REV. 781, 788 (1987); see also Owen M. Fiss, Free Speech and Social Structure, 71 IOWA L. REV. 1405, 1409-13 (1986) (expanding on the argument that individual speech deserves protection only to enrich public debate).

7. See, e.g., William W. Fisher III, Property and Contract on the Internet, 73 CHI.-KENT L. REV. 1203, 1212-18 (1998) (listing "semiotic democracy" as part of a vision of a "just and attractive culture"); Robert Post, Reconciling Theory and Doctrine in First Amendment Jurisprudence, 88 CAL. L. REV. 2353, 2368, 2367-68 (2000) (arguing that a participatory account of democracy requires individuals to understand their own "authorship of the state"); Daniel P. Tokaji, First Amendment Equal Protection: On Discretion, Inequality, and Participation, 101 MiCH. L. REV. 2409, 2505 (2003) (arguing that participation is important to the individual).

8. See Balkin, supra note 2, at 34-45; Kenneth L. Karst, Local Discourse and the Social Issues, 12 CARDOzo STUD. L. \& LITERATURE 1, 26-27 (2000) (discussing a similar concept of "cultural democracy"). 
to most of our lives, and when moments of political choice do come, our responses are shaped by the culture around us. As a result, freedom to participate in shaping culture is an overriding concern of the democratic self-governance view. That freedom is both affirmative and negative. It requires access to some common culture, so that everyone will have the resources to participate in culture and the freedom to debate and disagree about meaning.

While I find this conception of free speech attractive, its supporters have generally focused on transformation and criticism of copyrighted works as key elements of a democratic speech culture, rather than on simple copying. My discussion of copying as free speech is intended to complement theirs; I also hope that those who find other purposes in the First Amendment will find their preferred speech values implicated by the copying I discuss.

\section{B. Copyright and Fair Use}

Copyright has always posed a potential conflict with the First Amendment: A successful copyright infringement action gives the plaintiff the right to stop the defendant from printing, performing, or otherwise disseminating certain works. Infringing works can be seized and destroyed-book burning mandated by law. For nearly two centuries, though, courts and scholars did not think of copyright as posing any problems for free speech, in part because the First Amendment lacked its current scope and in part because copyright law rarely affected ordinary uses of copyrighted works. Consumers bought books and records, went to the movies, and listened to the radio, activities that gave them fewer opportunities to copy or modify copyrighted works than today's technologies allow, and any small-scale private copying was difficult for copyright owners to detect or address.

In the 1970 s, just as technology was beginning to make copying easy for ordinary people, scholars offered a convincing way to reconcile the two expanding bodies of law: ${ }^{9}$ The First Amendment prevents government suppression of speech, while copyright law provides an economic incentive to create and distribute the speech in the first place. Copyright is undoubtedly an engine of free expression, ${ }^{10}$ as it supports both large

9. See Robert C. Denicola, Copyright and Free Speech: Constitutional Limitations on the Protection of Expression, 67 CAL. L. REV. 283, $289-99$ (1979); Melville B. Nimmer, Does Copyright Abridge the First Amendment Guarantees of Free Speech and Press?, 17 UCLA L. REV. 1180, 1190 (1970); Harry N. Rosenfield, The Constitutional Dimension of "Fair Use" in Copyright Law, 50 NOTRE DAME LAW. 790, 796-99 (1975).

10. See Harper \& Row, Publishers v. Nation Enters., 471 U.S. 539, 558 (1985) ("[T]he Framers intended copyright itself to be the engine of free expression. By establishing a marketable 
corporations and individual artists so that they can afford to be in the business of speaking. Unfortunately, however, there is not much evidence about the ideal scope of copyright or its ideal term. ${ }^{11}$ Economic theory tells us that property rights in creative works will lead people to produce more creative works, at least up to the point where preexisting claims start to choke off latecomers' ability to create anything new, but no one knows the best place to draw the line. ${ }^{12}$ Moreover, there are numerous sources of creative works that are produced without the incentive of copyright (though they might not be published and distributed as effectively without copyright). Some academics write to spread their ideas or to get tenure; some artists make art because they cannot do otherwise or because they seek public accolades; some software programmers work on open source software because they like the challenge or believe in the ideal of open source or want peer recognition. ${ }^{13}$ As a result of the many intangibles and unknowns surrounding authorship, there is ample opportunity for debate about how to shape copyright law to best further the creation and dissemination of expression.

Despite these uncertainties, copyright law has steadily expanded. Copyright covers many more kinds of works-newspapers, computer programs, sculpture, musical works, sound recordings, architectural works, and others-than it did in the past. ${ }^{14}$ Congress has also expanded the scope of copyright, adding other exclusive rights to the exclusive right to control the reproduction of a work. ${ }^{15}$ For example, the 1909 Copyright Act granted authors rights over translations and dramatizations of their works, and in the

right to the use of one's expression, copyright supplies the economic incentive to create and disseminate ideas."); see also Paul Goldstein, Copyright and the First Amendment, 70 CoLuM. L. REV. 983, 989-90 (1970).

11. See PAUl GoldSTEIN, COPYRIGHT'S HighWAY: From GUTENBERG to THE CELESTIAL JUKEBOX 13 (rev. ed. 2003) ("Is copyright protection needed as an incentive to creative production? One reason the copyright optimists resist the pessimists' claim so strongly is that they know that, if put to rigorous empirical proofs, they could rarely answer this vital question affirmatively.").

12. See William M. Landes \& Richard A. Posner, An Economic Analysis of Copyright Law, 18 J. LEGAL STUD. 325, 332 (1989).

13. See, e.g., Yochai Benkler, Coase's Penguin, or Linux and The Nature of the Firm, 112 YALE L.J. 369, 424-26 (2002).

14. See 17 U.S.C. $\S 102$ (a) (2000) (protecting "original works of authorship fixed in any tangible medium of expression," including "(1) literary works; (2) musical works, including any accompanying words; (3) dramatic works, including any accompanying music; (4) pantomimes and choreographic works; (5) pictorial, graphic, and sculptural works; (6) motion pictures and other audiovisual works; (7) sound recordings; and (8) architectural works"). The first American copyright statute, by contrast, protected maps, books, and charts. See Act of May 31, 1790, ch. 15, 1 Stat. 124 (repealed 1802).

15. For a general overview of the expansion of U.S. copyright law over time, see JULIE E. COHEN ET AL., COPYRIGHT IN A GLOBAL INFORMATION ECONOMY 31-32 (2002). 
1976 Act this right was generalized into the derivative works right, ${ }^{16}$ which protects translations; dramatizations; movie versions; fictionalizations; abridgements; "or any other form in which a work may be recast, transformed, or adapted." 17 The derivative works right gives Disney the exclusive right to authorize stuffed animals, home videos, $t$-shirts, pencils, figurines, games, teapots, and anything else bearing images of characters from Disney's copyrighted works. It has assumed increasing economic importance over the last few decades. ${ }^{18}$

Meanwhile, new audiovisual technologies emerged and became culturally dominant. Because new works' greatest value often came from performance rather than reproduction, the reproduction right was inadequate to capture most of their economic value. Amendments to the Copyright Act expanded the copyright owner's exclusive right to authorize public performance, initially granted only to owners of dramatic works such as plays, to almost all works, including a public display right for works that are not performed. ${ }^{19}$ The meaning of "public" has also grown from the prototypical audience of a play; it now includes performances received by people in their homes either simultaneously, as with conventional television broadcasts, or piecemeal, as with Internet transmissions. ${ }^{20}$ The early limitation of the copyright owner's right to control only for-profit performances has been removed. ${ }^{21}$

Technological changes have also expanded the practical scope of copyright owners' rights. For example, although anyone can borrow a physical copy of a book from a library without the copyright owner's permission, borrowing an electronic version of the same book from the same library implicates the copyright owner's reproduction and display rights. $^{22}$ As a result of these changes, absent an applicable exception or

16. 17 U.S.C. $§ 103(\mathrm{a})$; see Tyler T. Ochoa, Copyright, Derivative Works and Fixation: Is Galoob a Mirage, or Does the Form(Gen) of the Alleged Derivative Work Matter?, 20 SANTA CLARA COMPUTER \& HIGH TECH. L.J. 991, 1018-20 (2004) (providing a history of the derivative works right).

17. 17 U.S.C. $\S 101$.

18. See 3 Melville B. Nimmer \& DAVID NimMER, NIMMER ON COPYRIGHT $\S 10.01$ [A] (2004); Benjamin A. Goldberger, How the "Summer of the Spinoff" Came To Be: The Branding of Characters in American Mass Media, 23 LOY. L.A. ENT. L. REV. 301, 302 (2003) (discussing how media companies are "reusing proven commodities whenever possible"). Winnie the Pooh merchandise, for example, generates an estimated one billion dollars per year for the Walt Disney Company. See Bruce Orwall, Disney Wins Bear-Knuckled, 13-Year Fight over Royalties, WALL ST. J., Mar. 30, 2004, at B1.

19. See COHEN ET AL., supra note 15, at 33-34.

20. See 17 U.S.C. $\$ 101$ (defining "publicly").

21. Under the 1909 Act, the performance right for nondramatic literary works and musical works extended only to public performances for profit. See Copyright Act of 1909, Pub. L. No. 349 , ch. 320, § 1(c), (e), 35 Stat. 1075, 1075-76 (amended 1976). The current performance and display rights have no such limit. See 17 U.S.C. $\S 106(4)-(6)$.

22. See LAWRENCE Lessig, Free CULTURE 143-44 (2004). 
defense, both playing the radio in a public place ${ }^{23}$ and e-mailing a copy of a news article to a friend ${ }^{24}$ violate the copyright owner's rights.

Beyond substantive changes in scope, copyright's procedure has changed in even more radically pro-ownership ways. Copyright used to be an opt-in system, requiring numerous formalities such as publication with proper notice of copyright that identified the owner and the publication date, and then timely renewal after a short initial term. ${ }^{25}$ Noncompliance dedicated a work to the public domain. Thus, many works were free for all to use as soon as they were published or shortly thereafter. Under the 1976 Act, however, copyright exists from the moment a work is created; it is not completely clear how one can dedicate a work to the public domain before its term of protection expires, though people have tried. ${ }^{26}$ Moreover, since 1989 , the absence of notice or even of a copyright owner's name is no guarantee that the work is free from copyright protection. ${ }^{27}$ Copyright initially lasted fourteen years, plus fourteen additional years if the copyright owner renewed the registration. The terms were lengthened over time; the renewal requirement remained until the 1976 Act, which established a unitary term of fifty years after the author's death. A work created today by an individual author will be protected by copyright for seventy years after the author's death, with no renewal necessary. ${ }^{28}$

Legally, then, copyright has been a one-way ratchet, covering more works and granting more rights for a longer time. Perhaps most important, copyright now affects ordinary people every day-some more than others, as the people being sued by the Recording Industry Association of America for uploading music have discovered to their sorrow. ${ }^{29}$ For all these reasons, copyright is a more significant restraint on what people can say now than ever before, and the initial free speech defense of copyright - that it enabled the existence of a robust creative sector by providing economic incentives to create-has been destabilized by social and technological change.

23. See generally Daniel Cantor, How Many Guests May Attend a Wedding Reception Before ASCAP Shows Up? Or, What Are the Limits of the Definition of Perform "Publicly" Under 17 U.S.C. § 101?, 27 COLUM. J.L. \& ARTS 79 (2003). In this case, the applicable exception would be 17 U.S.C. $\S 110(4)$, which allows public performances "without any purpose of direct or indirect commercial advantage," as long as the performance is not of a dramatic musical work, such as an opera.

24. See Bruce P. Keller \& JefFrey P. Cunard, Copyright LaW: A Practitioner's GUIDE $\S 14: 2.2$, at $14-10 \&$ n.26 (2002).

25. See COHEN ET AL., supra note 15, at 154-58 (providing an overview of the formalities).

26. See Corey Field, Copyright, Technology, and Time: Perspectives on "Interactive" as a Term of Art in Copyright Law, 50 J. COPYRIGHT SOC'Y U.S.A. 49, 67 (2003).

27. See 17 U.S.C. $\S 401$ (a) (2000) (providing that notice is voluntary).

28. See id. $\S 302$. For a brief history of term extensions, see Sherry Lynn Murphy, Note, Unlimited Congressional Power Under the Copyright Clause in Article I of the Constitution: Eldred v. Ashcroft, 38 U.S.F. L. REV. 525, 533-35 (2004).

29. See, e.g., Steve Knopper, 261 Music Fans Sued, Rolling STONE, Oct. 16, 2003, at 25. 
Copyright has always had some safety valves. If every unauthorized use of copyrighted works were infringement, many socially valuable activities would be impaired. For example, a book review would be unable to quote the book in question without permission, and permission could be withheld without a favorable review, a large payment, or both. As one way to solve this problem, courts developed the doctrine of fair use, codified in the 1976 Copyright Act.

The Act states that fair use of a copyrighted work "for purposes such as criticism, comment, news reporting, teaching (including multiple copies for classroom use), scholarship, or research"30 is not an infringement. This list is not exclusive, and not even inclusive--uses for those purposes may be infringing. Courts are instructed to consider four factors in determining fair use: (1) the purpose of the use, including whether it is commercial or nonprofit; (2) the nature of the copyrighted work, granting greater protection to fictional works than to factual ones and to unpublished works than to published ones; ( 3 ) the amount and substantiality of the portion used in relation to the original work; and (4) the effect of the use on the market for the original. ${ }^{31}$ This last factor includes the effect of an allegedly fair use on the market for authorized derivative works, so a movie version of a novel is not fair use even if the movie improves sales of the book. The Supreme Court has held that transformative uses-uses that add new material in a way that reflects critically on the original-are favored under the first factor and, relatedly, are assumed to be less likely to damage the copyright owner's markets. ${ }^{32}$

The derivative works right is difficult to reconcile with a transformationfriendly fair use. An article that takes quotations from fifty different sources and strings them together, or an audio collage that does the same thing, is a derivative work. An influential court decision held that sampling, defined as quotation from sound recordings in new songs, was "stealing" even though the resulting work contained a large amount of original material. ${ }^{33}$ Another court found that a book of Seinfeld trivia questions, containing material largely created by the authors and not by the producers of Seinfeld, was an infringing derivative work. ${ }^{34}$ The same thing happened to The Cat NOT in the Hat! A Parody by Dr. Juice, a commentary on the O.J. Simpson murder trial written and illustrated in the style of Dr. Seuss. ${ }^{35}$

30. 17 U.S.C. $\S 107$.

31. See id.

32. Campbell v. Acuff-Rose Music, 510 U.S. 569 (1994).

33. Grand Upright Music v. Warner Bros. Records, 780 F. Supp. 182, 183 (S.D.N.Y. 1991).

34. Castle Rock Entm't v. Carol Publ'g Group, 150 F.3d 132 (2d Cir. 1998).

35. Dr. Seuss Enters. v. Penguin Books USA, 109 F.3d 1394 (9th Cir. 1997). 
The derivative works right thus threatens to give copyright owners power to control interesting, creative, and culturally significant reuses of their works. Even a successful fair use defense is expensive, and the risk of such a lawsuit deters publishers from investing in potentially infringing works; that kind of self-censorship is traditionally a matter of concern to the First Amendment. ${ }^{36}$ As a result, a number of scholars have suggested that the derivative works right should be sharply cut back to provide some free speech breathing room for writers building on prior works (as we all must do, in one way or another). ${ }^{37}$

\section{The First Amendment Value of Copying}

This Essay's basic argument is that copyright's categories of valuable and protected speech are very different from the First Amendment's categories and that recent attempts to align them have been detrimental, particularly to copyright law. While using fair use to protect artists from censorship is appealing, other forms of copying are also integral to free speech today.

At the same time, it is difficult to imagine how we can allow easy access to copies in the service of a free and democratic culture without destroying the copyright owner's rights entirely. For example, Apple's "Rip. Mix. Burn." slogan encourages consumers to empower themselves by programming music according to their own preferences rather than adopting what is prepackaged. ${ }^{38}$ Making a mix $\mathrm{CD}$ is participatory and requires judgments about value and meaning, even if they are humble. It may express thoughts and emotions that the CD maker feels could be fully expressed no other way. ${ }^{39}$ But it also involves a significant amount of pure copying-something that taking "Rip. Mix. Burn." as a slogan for participatory culture slides over. ${ }^{40}$ Or, take television programming. If The Sopranos or Queer as Folk have a significant impact on our culture, then access to those programs improves a person's ability to participate in

36. See, e.g., Fla. Star v. B.J.F., 491 U.S. 524, 535-36 (1989); Riley v. Nat'l Fed'n of the Blind, 487 U.S. 781,794 (1988); N.Y. Times Co. v. Sullivan, 376 U.S. 254, 277-78 (1964).

37. See infra note 68 and accompanying text.

38. See Balkin, supra note 2, at 41.

39. See infra Subsection III.B.1; see also ROBERT LOPEZ \& JEFF MARX, Mix Tape, on AVENUE Q: ORIGINAL BROADWAY CAST RECORDING (RCA Victor Records 2003) ("Sometimes when someone / Has a crush on you / They'll make you a mix tape / To give you a clue."); SEMISONIC, Singing in My Sleep, on FEELING STRANGELY FINE (MCA 1998) ("Got your tape and it changed my mind / Heard your voice in between the lines / ... / Now I'm falling in love too fast / With you or the songs you chose / . . / I've been living in your cassette / It's the modern equivalent / Singing up to a Capulet / On a balcony in your mind.").

40. See Balkin, supra note 2, at 45 (arguing that democratic culture involves "nonexclusive appropriation, innovation, and combination"). 
making and interpreting that culture. There could be a problem for democracy when copyright owners set prices so high that some people can't read or watch what many others do. Letting people who have HBO write Sopranos fan fiction without fear of the copyright police is well and good, but they still need access to HBO in the first place; without access, there can be no derivative works and no water cooler conversation.

What follows? First, fair use, even in its older form, isn't enough to preserve citizens' access to the texts that shape their lives. That makes external limits on copyright owners' rights, such as exceptions for home copying and library uses, even more vital for preserving the practical conditions for freedom of expression. As Jack Balkin argues, it also increases the importance of noncopyright regulatory policies, such as regulation of cable providers to ensure they carry a wide range of content, provision of public libraries, and public education, to give people access to the basic elements of culture. ${ }^{41}$

Second, the copyright/First Amendment conflict may be much more intractable than some First Amendment theorists have concluded. One currently popular proposal is an expansion of fair use doctrine that privileges all or almost all transformative uses, defined as uses that add new meaning to a copyrighted work. The natural corollary is that the derivative works right would diminish to almost nothing. This is an extension of the current judicial trend, discussed in Part II, to favor transformative use and disfavor ordinary copying.

I will argue, however, that this proposal is unsatisfactory, because ordinary copying serves multiple speech values, from simple access to selfexpression to political persuasion. Copies can still serve free speech purposes when their culture-altering and culture-constituting effects aren't distilled into some new derivative work but remain in a viewer's mind or appear in her conversation-when their power derives from their content and not from a second comer's modifications. In other words, my copy of Rawls's $A$ Theory of Justice can serve valuable educational and political purposes even if it's an linauthorized copy and even if I don't write a response to it. But because fair use now demands that uses be transformative-adding new, critical meaning to the underlying workonly antagonists to the copyright owner's beliefs can be fair users. This is inconsistent with the historical scope of fair use and a bad idea to boot; there should be more than one fixed star in the fair use firmament. Part III elaborates on the argument for nontransformative uses, from prototypically self-expressive copying to copying for persuasion and copying as participation and affirmation.

41. See id. at 50-54. 
Part IV comments briefly on the First Amendment that emerges from copyright cases. By confining First Amendment analysis to the question of whether a particular use is an exception to a copyright owner's exclusive rights because it is transformative and critical, courts manage to preserve a libertarian vision of free speech fundamentally inconsistent with the overall structure of copyright. Paradoxically, the intersection of free speech and fair use serves to narrow both concepts rather than to preserve the multiple meanings and purposes of each.

Though there is no completely satisfactory way to reconcile copyright's claims with those of the First Amendment, the Conclusion suggests some ways to recognize that many kinds of copying deserve protection against ownership claims. This portion of the Essay is short because I believe that the conflicts between ownership and freedom I describe are in large part irreconcilable. Some forms of copyright law are better for free speech than others, no doubt, but any system of copyright will suppress speech, and some of that speech will be quite valuable in constitutional terms. My argument is not that copyright as a whole is an unconstitutional restriction on free speech. The core of copyright is a good thing, both as a matter of general policy and for a robust system of freedom of speech. I do not believe that anything is wrong with preventing well-off law professors from downloading the latest Eminem album from eDonkey. But we should be clear about the losses-both inevitable and avoidable-imposed by the current regime.

\section{LIMITING THE FIRST AMENDMENT BY INVOKING FAIR USE}

In 1998, Congress extended the copyright term by twenty years, prospectively and retrospectively, so that works copyrighted in 1923 and timely renewed will not enter the public domain until $2018,{ }^{42}$ assuming no further extension. Eric Eldred, a publisher of public domain works, sued, arguing that the Sonny Bono Copyright Term Extension Act (CTEA) violated both the "limited times" provision of Article I, Section 8 and the First Amendment. He lost at every level. ${ }^{43}$ As the arguments for and against the CTEA's constitutionality have been rehearsed many times, ${ }^{44}$ I will discuss only the role that fair use played in the analysis.

42. See 17 U.S.C.A. $\S 304$ (b) (West Supp. 2003).

43. Eldred v. Ashcroft, 537 U.S. 186, 193 (2003), aff g 239 F.3d 372 (D.C. Cir. 2001), aff $g$ 74 F. Supp. 2d 1 (D.D.C. 1999). That certiorari was granted merely to affirm, seven to two, the lower courts' conclusions that the CTEA was constitutional is itself evidence of the charisma exerted by First Amendment claims.

44. Any comprehensive list of articles would be extremely long. The briefs in Eldred provide a good overview of the arguments in the literature; many of the scholars who have written academic analyses of the CTEA also submitted (or joined) briefs to the Court. See Legal 
Justice Ginsburg wrote that, because of the fair use doctrine and the idea-versus-expression distinction, "copyright's built-in free speech safeguards," there can be no First Amendment problem as long as Congress stays within the "traditional contours" of copyright law. ${ }^{45}$ Beyond the plain problem that what Eldred was challenging was an extension of the copyright term far beyond its traditional bounds, to endorse this theory one would need a theory of what makes copyright law different from libel law, or from a variety of other speech regulations whose traditional forms have been substantially cabined by modern First Amendment jurisprudence. ${ }^{46}$

Though Justice Ginsburg's reasoning is incomplete, Eldred is only the latest in a line of similar cases. Courts have found that fair use saves copyright from constitutional infirmity. It has pride of place in many discussions of copyright's constitutionality. ${ }^{47}$ Indeed, one can read Eldred and other cases to hold that fair use is constitutionally required. ${ }^{48}$

Unfortunately, courts' understanding of fair use has restricted both fair use and the First Amendment, so that each seems to serve a single overriding value of protecting criticism rather than promoting the multiple values served by different kinds of copying and different kinds of speech. In particular, a vision of free speech that finds copyright unobjectionable as long as a fair use defense is available ignores the value of participating by affirming or agreeing with someone else's words.

Documents: Supreme Court, Eldred v. Ashcroft, http://www.eldred.cc/legal/supremecourt.html (last visited Nov. 24, 2004) (containing links to briefs on both sides).

45. Eldred, 537 U.S. at 221.

46. Copyright appears in the Constitution, U.S. CoNST. art. I, $\S 8, \mathrm{cl} .8$, whereas libel does not. But libel law is state law, and federalism is structured by the Constitution. Prior to New York Times Co. v. Sullivan, 376 U.S. 254 (1964), states exercised complete policy discretion, not controlled by the First Amendment, over the contours of libel law. The same is currently true of copyright, though the decisionmaker is Congress rather than state courts or legislatures. Moreover, copyright's appearance in the Constitution tells us nothing about the constitutionally acceptable scope of copyright law. As discussed supra notes 14-28 and accompanying text, our copyright is very different from the Framers', as is our First Amendment. See generally L. Ray Patterson \& Craig Joyce, Copyright in 1791: An Essay Concerning the Founders' View of the Copyright Power Granted to Congress in Article I, Section 8, Clause 8 of the U.S. Constitution, 52 EMORY L.J. 909 (2003).

47. See, e.g., A \& M Records v. Napster, 114 F. Supp. 2d 896, 922 (N.D. Cal. 2000) ("[F]ree speech concerns are protected by and coextensive with the fair use doctrine." (internal quotation marks omitted)), aff'd in part and rev'd in part, 239 F.3d 1004 (9th Cir. 2001); L.A. Times v. Free Republic, 54 U.S.P.Q.2d (BNA) 1453, 1472 (C.D. Cal. 2000) (holding that free speech concerns "are subsumed within the fair use Analysis"); Denicola, supra note 9, at 293-99; Goldstein, supra note 10, at 1011-15, 1017-22; L. Ray Patterson, Free Speech, Copyright, and Fair Use, 40 VAND. L. REV. 1, 36-48 (1987).

48. See Stephen M. McJohn, Eldred's Aftermath: Tradition, the Copyright Clause, and the Constitutionalization of Fair Use, 10 MICH. TELECOMM. \& TECH. L. REV. 95 (2003), available at http://www.mttlr.org/volten/mcjohnTYPE1-27.pdf. 


\section{A. How the First Amendment Value of Dissent Maps onto Transformative Fair Use}

Critical, transformative uses of copyrighted works against their owners' wills are analogous to the speech of political protesters attacking received wisdom, whose actions are generally thought to be at the heart of the First Amendment's protections. Courts are therefore wary when a copyright owner upset by a critical message attempts to suppress it. Core First Amendment values seem to have exercised a gravitational pull, reshaping fair use in the First Amendment's image.

It is true that fair use isn't the only thing that, according to courts, saves copyright from the constitutional dumpster. The distinction between protectable expressions and unprotectable ideas and facts is the other pillar of copyright's compatibility with free speech. ${ }^{49}$ But the idea-versusexpression distinction gets less play than fair use in the recent literature on copyright and the First Amendment. ${ }^{50}$ The line between idea and expression of idea is possibly even more nebulous than that between fair and unfair use, and the difference between fact and expression can be fairly tricky as well. ${ }^{51}$ Such self-evidently vague tests are more embarrassment than aid to copyright supporters. The four-factor fair use test is also vague, but policy concerns about whether to categorize something as freely usable or as private property are easier to incorporate into the fair use balancing test than into a determination of what is fact or idea and what expression. ${ }^{52}$ Fair

49. See, e.g., Harper \& Row, Publishers v. Nation Enters., 471 U.S. 539, 556, 560 (1985); Zacchini v. Scripps-Howard Broad. Co., 433 U.S. 562, 577 n.13 (1977); see also Suntrust Bank v. Houghton Mifflin Co., 268 F.3d 1257, 1263-64 (11 th Cir. 2001).

50. The First Amendment value of free use of facts does show up in the literature on proposed extracopyright protection for databases, which generally reasons that, if copyright is constitutional because it doesn't protect facts, plugging that hole would be unconstitutional. See, e.g., Yochai Benkler, Constitutional Bounds of Database Protection: The Role of Judicial Review in the Creation and Definition of Private Rights in Information, 15 BERKELEY TECH. L.J. 535, 587-600 (2000); Justin Hughes, How Extra-Copyright Protection of Databases Can Be Constitutional, 28 U. DAYTON L. REV, 159, 181-83, 189-202 (2002).

51. See, e.g., Peter Pan Fabrics v. Martin Weiner Corp., 274 F.2d 487, 489 (2d Cir. 1960) (Hand, J.) ("Obviously, no principle can be stated as to when an imitator has gone beyond copying the 'idea,' and has borrowed its 'expression.' Decisions must therefore inevitably be ad hoc."); Nichols v. Universal Pictures Corp., 45 F.2d 119, 122 (2d Cir. 1930) (Hand, J.) (holding that "wherever [the line between idea and expression] is drawn[] will seem arbitrary").

52. One recent article even advocated a "fair use return to the idea-expression dichotomy" as a way to "add gradation between all-or-nothing results," suggesting how fair use operates to take everything, including the role of ideas and facts, into account. Jon M. Garon, Normative Copyright: A Conceptual Framework for Copyright Philosophy and Ethics, 88 CORNELL L. REV. 1278, 1341-42 (2003) (capitalization altered); see also Golan v. Ashcroft, 310 F. Supp. 2d 1215, 1220 (D. Colo. 2004) (citing Eldred for the proposition that "the fair use defense allows the public to use some of the facts, ideas and expressions in a copyrighted work"). 
use even takes the factual nature of a work into account, ${ }^{53}$ according less protection to factual works than fictional or highly expressive ones. ${ }^{54}$

Fundamentally, the kinds of activities defended by copyright minimalists, such as reprinting old works that have fallen out of print or using existing pictures or music as part of a new work, currently tend to seem more like fair use than like copying ideas or facts. (This is, of course, related to the increasing identification of fair use with the First Amendment, a self-sustaining feedback loop.) In Harper \& Row, Publishers v. Nation Enterprises, for example, the issue was whether the Nation's unauthorized use of extensive paraphrase and of 300 to 400 words directly from President Ford's forthcoming autobiography was protected by the First Amendment. ${ }^{55}$ Despite a strong dissent arguing that the words that President Ford used were themselves facts of historical interest, ${ }^{56}$ the majority and the dissent mainly argued about the meaning of fair use. ${ }^{57}$

In current jurisprudence, then, fair use is the last safe haven of copyright refugees. In turn, fair use increasingly requires transformation, that is, the addition of new material or a new, critical perspective.$^{58}$ In 1990 , Judge Pierre Leval proposed the transformative test in his influential article in the Harvard Law Review, ${ }^{59}$ and it was adopted by the Supreme Court in its next fair use decision. ${ }^{60}$ Leval viewed transformativeness as critical to whether a use "fulfill[ed] the objective of copyright law to stimulate creativity." ${ }^{61}$ Uses that added value to the original brought something new and creative into the world, so they might be justified even if the copyright owner objected, while mere repackaging or republication was not creative and therefore did not deserve protection from liability. ${ }^{62}$ Leval developed the test by arguing from within copyright doctrine and did not draw directly from First Amendment principles. Over time, however, transformative use has become identified with protection for free speech, which thereby comes to be identified with fair use. ${ }^{63}$

53. See 17 U.S.C. $\$ 107(2)(2000)$.

54. See, e.g., NRA v. Handgun Control Fed'n, 15 F.3d 559, 562 (6th Cir. 1994).

55. 471 U.S. 539 (1985).

56. See id. at 580-87 (Brennan, J., dissenting).

57. See id. at 560-69 (majority opinion); id. at 590-604 (Brennan, J., dissenting); see also Suntrust Bank v. Houghton Mifflin Co., 268 F.3d 1257, 1266-67, 1276 (11 th Cir. 2001) (rejecting publisher's defense that Alice Randall copied only ideas behind Gone with the Wind because Randall copied specific characters and situations, but holding that publisher's fair use defense was likely to succeed).

58. See, e.g., Jeremy Kudon, Note, Form over Function: Expanding the Transformative Use Test for Fair Use, 80 B.U. L. REV. 579 (2000) (surveying post-Campbell cases).

59. Pierre N. Leval, Toward a Fair Use Standard, 103 HARV. L. REV. 1105, 1111 (1990).

60. See Campbell v. Acuff-Rose Music, 510 U.S. 569, 579 (1994).

61. Leval, supra note 59, at 1111.

62. See id.

63. See, e.g., Elvis Presley Enters. v. Passport Video, 357 F.3d 896, 898 (9th Cir. 2004) (Noonan, J., dissenting) ("The district judge's job in reviewing uses claimed to be transformative 
The most visible instance of the increasing identification of transformative fair use with free speech was the Wind Done Gone case, Suntrust Bank v. Houghion Mifflin Co ${ }^{64}$ Author Alice Randall retold the story of Margaret Mitchell's Gone with the Wind with new characters and new interpretations of events in response to the racism of the original, thereby creating a derivative work. In reversing the district court's grant of a preliminary injunction, the court of appeals emphasized that Randall's retelling was critical and transformative. The court was particularly impressed by the fact that the Mitchell estate forbids any authorized derivative works based on Gone with the Wind to mention homosexuality or miscegenation, while Randall made both part of her plot. ${ }^{65}$ The Mitchell estate was trying to use copyright law as its own private Comstock Act. Fair use stood in the way of such censorship. ${ }^{66}$

Randall was criticizing the dominant paradigm, the myth of white Southern gentility, whose most effective piece of propaganda is Gone with the Wind. As a critic of a popular cultural icon, Randall fit the model of a rebel speaking truth to power and suffering for it. Like a protester burning an American flag, she seized on a powerful symbol and altered its meaning; giving the Mitchell estate control of how Gone with the Wind is reinterpreted would be like requiring that the flag always be treated with respect.

The Wind Done Gone decision now seems to many scholars to be an archetypical fair use (and free speech) case. ${ }^{67}$ As noted above, the derivative works right invoked by the Mitchell estate is in obvious tension with transformative fair use because it prevents other people from adding creative content and meaning to copyrighted works without the owner's permission. As a result, many of copyright's critics propose a cutback in the right in order to ameliorate copyright's conflict with free speech and eliminate the possibility that the next Alice Randall will lack the resources to litigate against the next Mitcheil estate. ${ }^{68}$ Modest proposals to pare down

is particularly important as the fair use doctrine is intended to preserve the values enshrined in the First Amendment."), amending 349 F.3d 622 (9th Cir. 2003), cert. denied, 124 S. Ct. 2886 (2004).

64. 268 F.3d 1257 (11th Cir. 2001).

65. Id. at 1282 (Marcus, J., concurring specially); see id. at $1270 \mathrm{n} .26$ (majority opinion).

66. See id. at 1263 ("[C]opyright laws were enacted in part to prevent private censorship ....").

67. See, e.g., LAWRENCE LeSSIG, 'THE FUTURE OF IDEAS: THE FATE OF THE COMMONS IN A CONNECTED WORLD 198-99 (2001); NEIL WEINSTOCK NETANEL, COPYRIGHT'S PARADOX: PROPERTY IN EXPRESSION/FREEDOM OF EXPRESSION (forthcoming 2005) (manuscript at 1-2, on file with author); Benkler, supra note 2, at 173, 195-96 (using case as one of three core examples); Wendy J. Gordon, Authors, Publishers, and Public Goods: Trading Gold for Dross, 36 LOY. L.A. L. REV. 159, 188-89 (2002).

68. See, e.g., NETANEL, supra note 67 (manuscript at 56-57, 122) (arguing that "oppositional expression" is a central First Amendment value threatened by current copyright law); C. Edwin Baker, First Amendment Limits on Copyright, 55 VAND. L. REV. 891, 941 (2002) ("Possibly the 
the derivative right are appealing but unlikely to solve the doctrinal problems that copyright causes for the First Amendment. Before the 1976 Act, indeed, the reproduction right did all the work that the derivative works right now does; a century ago, one could infringe a book by turning it into a play or a movie without the author's permission. ${ }^{69}$ A cutback in the derivative works right wouldn't help decide whether the Free Republic website infringed by copying whole newspaper articles and then letting people annotate them to reveal the mainstream media's liberal biases ${ }^{70}$ or whether full-scale sculptures made from a postcard in order to highlight the banality of popular art infringed the photographer's copyright. ${ }^{71}$ In general, the line between reworking and repeating is difficult to sustain. Many of the ways in which people use copyrighted works creatively involve both copying and reworking. ${ }^{72}$ As Picasso (or someone else) said, "Good artists borrow; great artists steal." 73

More broadly, identifying the protection of dissenters as one way fair use serves free speech goals is reasonable. But the logical chain linking criticism, the First Amendment, and transformative fair use can make those concepts seem coterminous with one another as far as copyright defendants are concerned. The values of public access and dissemination that were also traditionally part of fair use, and part of many theories of free speech, get left behind.

highest priority is to protect transformative uses . . . ."); Guy Pessach, Copyright Law as a Silencing Restriction on Noninfringing Materials: Unveiling the Scope of Copyright's Diversity Externalities, 76 S. CAL. L. REV. 1067,1104 \& n.116 (2003); Rubenfeld, supra note 2, at 5, 48, 53 ("I argue that copyright's core prohibition against piracy is consistent with the freedom of imagination, but that a good deal of copyright law outside this core is not. . . I conclude that copyright's prohibition of unauthorized derivative works is unconstitutional...."). I agree that the derivative works right is problematic under a First Amendment analysis, see Tushnet, supra note 1 , at 77 , but my focus here is on the dangers of identifying derivative works as the central First Amendment problem with copyright's scope.

69. See, e.g., Sheldon v. Metro-Goldwyn Pictures Corp., 81 F.2d 49, 55-56 (2d Cir. 1936).

70. See L.A. Times v. Free Republic, 54 U.S.P.Q.2d (BNA) 1453 (C.D. Cal. 2000). Jed Rubenfeld recognizes the problem posed by the Free Republic case, which was that the copiers were both reproducing entire articles and adding new material. He therefore argues for an extremely limited definition of "reproduction" that would exclude reproduction plus commentary. See Rubenfeld, supra note 2, at 50-52.

71. See Rogers v. Koons, 960 F.2d 301 (2d Cir. 1992).

72. See, e.g., John Leland, Beyond File-Sharing, a Nation of Copiers, N.Y. TIMES, Sept. 14, 2003, $\S 9$ (Sunday Styles), at 1 ("In a nation that flaunts its capacities to produce and consume, much of the culture's heat now lies with the ability to cut, paste, clip, sample, quote, recycle, customize and recirculate. ... D.J.'s, file sharers, handbag cloners, student plagiarists and some bloggers simply do what brand companies do: they reproduce work made elsewhere at lower rates, adding their own signature and mix.").

73. This statement, or something like it, is usually attributed to Pablo Picasso. Variants exist, including T.S. Eliot's "Immature poets imitate; mature poets steal." See Debra L. Quentel, "Bad Artists Copy. Good Artists Steal.": The Ugly Conflict Between Copyright Law and Appropriationism, 4 UCLA ENT. L. REV. 39, 39 n.* (1996). 
B. How the Identification of Transformative Use with the First Amendment Obscures Other Free Speech Values

Does transformation define the category of speech that cannot be controlled through copyright, or is it an example of such speech? The difference is subtle but vital. An exclusive focus on transformation in thinking about copyright and freedom of speech is likely to support further expansions of copyright in two ways, one external to fair use and one internal.

\section{Copyright's Other Speech-Protective Limits}

The identification of fair use and the idea/expression dichotomy as the guarantors of free speech hides all the other aspects of copyright that enable free speech. ${ }^{74}$ A partial list includes the lack of a general performance right for sound recordings, ${ }^{75}$ limits on the performance and display rights to public performances and displays; ${ }^{76}$ the denial of copyright to U.S. government works; ${ }^{77}$ the first-sale doctrine, which allows owners of a copy to resell or otherwise dispose of it; ${ }^{78}$ various exceptions for schools and libraries; ${ }^{79}$ a variety of compulsory licenses; ${ }^{80}$ the merger doctrine, which allows copying when there are only a small number of ways to express an idea ${ }^{81}$ and even the (theoretically) limited term. ${ }^{82}$ All of these provide some freedom for use of copyrighted works in ways that are relevant to the First Amendment, but absent recognition of that function, all could be eliminated by Congress, as indeed similar limits such as the notice and renewal requirements have been eliminated in the past. ${ }^{83}$ Eldred may suggest that fair

74. Cf. L. Ray Patterson, Folsom v. Marsh and Its Legacy, 5 J. INTELL. PROP. L. 431, 431 (1998) ("[F]air use today continues to be an engine for expanding the copyright monopoly.").

75. See 17 U.S.C. $\$ 106(2000)$.

76. See id.

77. See id. $\S 105$.

78. See id. $\$ 109$.

79. See id. $\S \S 108,110$.

80. See id. $\S 111$ (d) (cable television); id. $\S 114(\mathrm{~d})$ (certain digital audio transmissions); id. $\S 115$ (phonorecords of nondramatic musical works); id. $\S 118$ (noncommercial broadcasting); id. $\S 119$ (certain satellite retransmissions). Compulsory licenses limit the rights of copyright owners, giving them the right to compensation for use but not the right to refuse permission to anyone.

81. See, e.g., Kregos v. Associated Press, 937 F.2d 700, 705 (2d Cir. 1991) (discussing merger as a defense to infringement); Morrissey v. Procter \& Gamble Co., 379 F.2d 675 (1st Cir. 1967) (holding that instructions for a sweepstakes contest couldn't be copyrighted because the subject matter could only be expressed in a very limited number of ways).

82. See 17 U.S.C. $\S \S 301-302$.

83. The constitutionality of eliminating the registration, notice, and renewal requirements is currently being challenged. See Amended Complaint for Declaratory Judgment, Kahle v. Ashcroft (N.D. Cal. filed Mar. 22, 2004) (No. C. 04-1127 BZ). The copyright term could not be extended infinitely in a single step because of the constitutional specification of "limited Times," U.S. CONST. art. I, $\S 8$, cl. 8 , but it arguably could be extended piecemeal indefinitely. The merger 
use is constitutionally required, despite its origins as a common law gloss on the statute, but the Court said nothing about these other statutory limits.

In particular, the exclusion of private performances and displays and the first-sale doctrine, though historically of major importance, are decreasingly relevant to ordinary uses of copyrighted works due to technological change and the expansion of what is considered a public performance. This may explain why fair use is being asked to do too much work. Commentators have noted a tendency to claim as fair use activities like private reading or listening that were never before within the scope of the exclusive rights, because fair use seems to be the only thing left to protect these traditional activities. ${ }^{84}$ But fair use, with its balancing apparatus, is ill suited to protecting activities that are at the core of ordinary uses of copyrighted works; it is supposed to deal with unusual or marginal activities.

Fair use and the idea/expression dichotomy have the virtue of flexibility, unlike most of these other speech-protective rules, because they're nontechnical, judge-made and judge-elaborated doctrines. ${ }^{85}$ But they also have the horrendous defect of their virtue-they require case-bycase application and provide no predictability for a publisher curious to know what it can do outside the barest minimum of quotation of literary works. On their own, idea/expression and fair use are not good enough to sustain free speech. Yet we can hardly imagine a court requiring any of the other, more detailed exceptions listed above as a constitutional matter. Issues such as the scope of the performance right and compulsory television retransmission licenses seem quintessentially legislative choices, even more resistant to judicial line drawing than the copyright term. Thus, courts and doctrine may seem irrelevant, despite copyright's threat to free speech. ${ }^{86}$

Jack Balkin has recently emphasized that the question of judicial competence makes it crucial to broaden the arena in which academics, lawyers, and activists seek to protect speech. ${ }^{87}$ Other social institutions, such as the Federal Communications Commission, universities, and

doctrine might also be hard to extirpate insofar as it relates to whether a work is an original work of authorship, that is, whether the work evinces any creative spark. See Feist Publ'ns v. Rural Tel. Serv. Co., 499 U.S. 340, 346 (1991) (holding that originality is a constitutional requirement for copyright protection).

84. See, e.g., LESSIG, supra note 22, at 143-45; A Copyfighter's Musings, http://blogs.law.harvard.edu/cmusings/2004/01/16 (Jan. 16, 2004, 16:01:56 EST).

85. Now codified, insofar as they can be, in the Copyright Act. See 17 U.S.C. $\S$ 102(b), 107.

86. Cf. Balkin, supra note 2 , at 50-54 (arguing that legislative, administrative, and technological decisionmakers will as a practical matter exercise more control over freedom of speech than will courts); Paul M. Schwartz \& William Michael Treanor, Eldred and Lochner: Copyright Term Extension and Intellectual Property as Constitutional Property, 112 YALE L.J. $2331,2403-04$ (2003) (arguing that the judiciary lacks competence to evaluate changes in copyright law).

87. See Balkin, supra note 2, at 50-54. 
libraries, have roles to play in preserving freedom for individuals in the face of expansive claims by copyright owners. ${ }^{88}$ Freedom of speech, in other words, is too important to be left to the courts. My focus here, however, is on how fair use has become such a thin reed on which to rest claims that copyright does not threaten freedom of expression.

\section{The Redefinition of Fair Use To Suppress Unauthorized Copying}

While extrajudicial and structural limits to copyright are under attack, fair use law has been realigned around transformative use, in which the user does more than simply copy the original work. ${ }^{89}$ Transformation is not sufficient to produce a fair use finding, but it is increasingly necessary. ${ }^{90}$ At the same time, academics have used transformativeness to argue that copyright has gone too far in suppressing speech. ${ }^{91}$ Fair use, the reasoning goes, should have protected the book on the O.J. Simpson trial done in the style of Dr. Seuss and the unauthorized Seinfeld trivia book. ${ }^{92}$

In many cases, it is possible to disagree about what counts as "transformation," or the older term, "productivity." 93 Courts have found transformation-and therefore, fair use-in minimized images of larger pictures, used to index the pictures for an Internet search engine, ${ }^{94}$ and in photographs taken for a modeling portfolio that were used instead for a news report. ${ }^{95}$ This is not transformation of the copyrighted works, only of their contexts, as a copyright owner would quickly discover were she to attempt to register the smaller image or news photo as a derivative work. The Copyright Office would reject the claim that the works had been "recast, transformed, or adapted" as required to create a derivative work

88. See ThOMAS I. EMERSON, THE SySTEM OF FREedOM OF EXPRESSION 3-5 (1970) (identifying freedom of expression as the product of institutions, such that true freedom of expression requires affirmative government action as well as limits on state power).

89. See, e.g., NXIVM Corp. v. Ross Inst., 364 F.3d 471, 484 (2d Cir. 2004) (Jacobs, J., concurring) ("[T]he fair use defense exists to encourage the creation of original works . . .." (emphasis added)); Am. Geophysical Union v. Texaco, 60 F.3d 913, 923 (2d Cir. 1995) (stating that transformative use is "central"); Diane Leenheer Zimmerman, The More Things Change, the Less They Seem "Transformed": Some Reflections on Fair Use, 46 J. COPYRIGHT SOC'Y U.S.A. 251,257 (1998) ("[T]he presence or absence of transformation has become the linchpin on which post-Campbell fair use cases tend to turn.").

90. See supra notes 55-63 and accompanying text.

91. See supra note 68.

92. Cf. Castle Rock Entm't v. Carol Publ'g Group, 150 F.3d 132 (2d Cir. 1998); Dr. Seuss Enters. v. Penguin Books USA, 109 F.3d 1394 (9th Cir. 1997).

93. See, e.g., David Nimmer, "Fairest of Them All" and Other Fairy Tales of Fair Use, LAW \& CONTEMP. PROBS., Winter/Spring 2003, at 263, 269-77 tbl. (offering chart with some very provocative classifications of fact patterns from cases, which often differ from courts' determinations); Zimmerman, supra note 89, at 251-52, 258-59.

94. See Kelly v. Arriba Soft Corp., 336 F.3d 811, 818-20 (9th Cir. 2003).

95. See Núñez v. Caribbean Int'l News Corp., 235 F.3d 18, 22-23 (1 st Cir. 2000). 
under the Copyright Act. ${ }^{96}$ Nonetheless, courts apparently believe that a finding of transformation is necessary for fair use, and they therefore strain to find transformation where they conclude that a defendant ought to prevail. $^{97}$

The consequence of this emphasis is that nontransformative copying, including plain old photocopying even in educational or scientific contexts, begins to look unfair. ${ }^{98}$ If all the scholar, researcher, or student wants is an ordinary copy of the work, there is no reason that she shouldn't have to pay the copyright owner for it. Any transformation she makes later may be a fair use, but the initial copy doesn't have that transformative gloss. This is so despite the historic status of pure copying at the core of fair use, which is reflected in the portion of the preamble of section 107 of the Copyright Act that mentions "multiple copies for classroom use." Done Gone court omitted those words when quoting the preamble in its discussion of how fair use serves First Amendment purposes.) ${ }^{100}$

96. 17 U.S.C. $\$ 101$ (2000) (emphasis added) (defining derivative works); see Lee v. A.R.T. Co., 125 F.3d 580, 581-82 (7th Cir. 1997) (noting that the Copyright Office rejected an attempted registration of a work that had simply been recontextualized by attaching it to a decorative tile).

97. See 4 NIMMER \& NIMMER, supra note 18, § 13.05[A][1][b], at 13-162 (criticizing cases that use "'not transformative' as a shorthand for 'not fair,' and correlatively 'transformative' for 'fair"'). The Kelly and Núnez cases correctly recognize that context changes meaning, but they're right in a way that copyright law generally can't recognize, because they involve complete, wholesale copying as well as recontextualization. See Robert H. Rotstein, Beyond Metaphor: Copyright Infringement and the Fiction of the Work, 68 CHI.-KENT L. REV. 725, 727 (1993) (arguing that current copyright law fails to recognize that works subject to copyright are "unstable and dependent on context"); $i d$. at 735-38 (discussing literary theories of intertextuality, which emphasize that all works are changed by the varying contexts in which readers encounter them). In the same way, a music video using a happy song playing over images of death and destruction would give the song new meaning, but it would be unlikely to be found transformative under current doctrine. See Abilene Music v. Sony Music Entm't, 320 F. Supp. 2d 84, 92 (S.D.N.Y. 2003) (discussing a contextually transformative use of What a Wonderful World). Transformation is a malleable concept, especially with shorter and smaller works whose surrounding context is usually easy to see, and it is difficult to predict when a court might agree that changed surroundings were sufficiently transformative to constitute fair use.

98. See, e.g., Princeton Univ. Press v. Mich. Document Servs., 99 F.3d 1381 (6th Cir. 1996) (en banc); Am. Geophysical Union v. Texaco, 60 F.3d 913 (2d Cir. 1995); see also Nihon Keizai Shimbun, Inc. v. Comline Bus. Data, 166 F.3d 65, 69, 72 (2d Cir. 1999) (finding that absence of transformation in a case involving translation of news items weighed heavily against fair use). Nontransformative uses are also presumed to cause market harm, making a finding of fair use extremely unlikely. See, e.g., Dr. Seuss Enters. v. Penguin Books USA, 109 F.3d 1394, 1403 (9th Cir. 1997); Oasis Publ'g Co. v. West Publ'g Co., 924 F. Supp. 918, 929 (D. Minn. 1996); Laura G. Lape, Transforming Fair Use: The Productive Use Factor in Fair Use Doctrine, 58 ALB. L. REV. 677, 716-17 (1995).

99. 17 U.S.C. \& 107; see also Williams \& Wilkins Co. v. United States, 487 F.2d 1345, 1351, 1353-57 (Ct. Cl. 1973) (upholding copying of entire articles by library for research purposes as fair use), aff'd by an equally divided Court, 420 U.S. 376 (1975); MARSHALL A. LEAFFER, UNDERSTANDING COPYRIGHT LAW 431 (3d ed. 1999).

100. See Suntrust Bank v. Houghton Mifflin Co., 268 F.3d 1257, 1264 (11th Cir. 2001) ("“[P]urposes such as criticism, comment, news reporting, teaching...., scholarship, or research' ... are at the heart of fair use's protection of the First Amendment . . .." (quoting 17 U.S.C. $\$ 107(2000)$ ) (first omission in original)). 
Some scholars have persuasively argued that the scope of fair use is shrinking because courts and commentators have adopted the idea that fair use is only relevant for instances of market failure, and copyright proprietors have successfully urged that market failures are generally curable by licensing schemes, which are even easier to apply in digital markets. ${ }^{101}$ Market failure and market-creating schemes are definitely part of the story, but I want to focus on how First Amendment reasoning has interacted with this trend to apotheosize transformation as fair use. Transformative uses have always been easy examples of market failures that aren't correctable by industrywide licensing schemes, as Wendy Gordon recognized in her influential article on fair use as market failure. ${ }^{102}$ Copyright owners have noneconomic reasons to prohibit many transformative uses, especially critical or parodic uses. ${ }^{103}$ Such uses seem to have major positive externalities that can't be captured by the transformative user, making her insufficiently willing to pay for a license; ${ }^{104}$ they vary widely in nature and tend to focus on one or a few works at a time, so blanket licenses seem inappropriate in a way that they do not for systematic photocopying or playing music on the radio. ${ }^{105}$

101. See, e.g., Raymond Shih Ray Ku, Consumers and Creative Destruction: Fair Use Beyond Market Failure, 18 BERKELEY TECH. L.J. 539, 557-63 (2003) (summarizing the literature and the successes of the market failure approach). Examples of reasoning that digital licensing will largely eliminate the need for fair use can be found in GOLDSTEIN, supra note 11, at 207 (arguing that the perceived need for fair use will decrease as a result of digital licensing, though normative justifications might remain); BRUCE A. LEHMAN, INTELLECTUAL PROPERTY AND THE NATIONAL INFORMATION INFRASTRUCTURE: THE REPORT OF THE WORKING GROUP ON INTElleCtUAL PROPERTY RightS 82 (1995), available at http://www.uspto.gov/web/offices/ com/doc/ipnii/ipnii.pdf; and Tom W. Bell, Fair Use vs. Fared Use: The Impact of Automated Rights Management on Copyright's Fair Use Doctrine, 76 N.C. L. REV. 557, 583-84 (1998). Trotter Hardy notes that recent technological developments lower the costs of "drawing borders" and "monitoring border trespasses." Trotter Hardy, Property (and Copyright) in Cyberspace, 1996 U. CHI. LEGAL. F. 217, 259-60. This may mean the need for fair use will decrease.

102. Wendy J. Gordon, Fair Use as Market Failure: A Structural and Economic Analysis of the Betamax Case and Its Predecessors, 82 COLUM. L. REV. 1600 (1982).

103. Id. at 1632-35.

104. Id. at 1630-32.

105. Harry Fox Agency (HFA), the industry organization that licenses mechanical reproduction of musical works on behalf of American musical copyright owners, licenses only nondramatic musical works, not operas or musicals or even cabaret-style presentations of songs from a musical. HFA, What Does HFA Do?, http://www.harryfox.com/public/hfaPurpose.jsp (last visited Nov. 24, 2004); see also 17 U.S.C. § 115(a)(2) (2000) (setting forth statutory scheme for compulsory licenses, which underlies HFA licensing). HFA no longer offers synchronization licenses, which allow use of a musical work in an audiovisual work, such as a movie or music video. See Nat'l Music Publishers' Ass'n, What License Do You Need?, http://www.nmpa.org/ $\mathrm{hfa} /$ /icensing.html (last visited Nov. 24, 2004). SoundExchange, which administers compulsory licenses for digital performances such as those provided by Internet radio stations, licenses only certain noninteractive webcasts. Interactive streams, which give users more control over the music they hear, and digital downloads require individual negotiation with record labels. See SoundExchange, Licensing 101, http:/www.soundexchange.com/licensing $101 . h t m l$ (last visited Nov. 24, 2004). Samples, which are the most obvious transformative derivative use of sound recordings, are also individually licensed despite being relatively common in the current music 
Even for those who accept the market failure paradigm, then, transformative use seems ineradicably to be fair use. At the same time, transformative uses fit comfortably in an older, constitutionalized discourse about criticism, contrarianism, protest, offensiveness, and unpopularity. ${ }^{106}$ So, as fair use faces internal pressure from copyright theories determined to make it obsolete, transformative use can easily borrow from First Amendment theories to bolster its economic argument. Because the defense is focused on criticism, however, it lacks any ability to defend pure copying on First Amendment grounds and thus cedes a large segment of formerly fair uses to copyright owners. The Clinton Administration's highly protectionist white paper, Intellectual Property and the National Information Infrastructure, summarizes this trend with its revealing conclusion that "[c]ommercial uses that involve no 'transformation' by users and harm actual or potential markets will likely always be infringing, while nonprofit educational transformative uses will likely often be fair."

This dynamic is, I believe, why it is less surprising than many people seemed to think that major copyright owners, including Microsoft, were on Alice Randall's side in the Wind Done Gone case. ${ }^{108}$ Realistically,

industry. The Copyright Clearance Center (CCC), which licenses numerous print sources, licenses only duplication of excerpts of material in its repertoire, and that only for internal corporate use; it does not license duplication of entire works or creation of derivative works. See CCC, Annual Authorization Service (AAS): Frequently Asked Questions, http://www.copyright.com/Help/ HelpAASFAQ.asp (last visited Nov. 24, 2004). For academic coursepacks, the CCC simply passes through a publisher's price and other restrictions, possibly simplifying negotiation but not standardizing anything. Given major efforts by the music industry and the CCC to solve market failure problems by creating one-stop shopping, the absence of any attempt to license derivative uses on an industrywide basis is strong evidence that such a licensing market is unlikely to develop.

106. See, e.g., Baker, supra note 68, at 942 ("Especially if the Press Clause is thought to support either a complex or liberal pluralist notion of democracy, the First Amendment should especially protect dissident or norm-challenging uses of copyrighted materials. This consideration provides the constitutionally required reason for an expansive reading of the privilege to engage in transformative uses." (footnotes omitted)); Balkin, supra note 2, at 47 ("Dissent is central to this [democratic culture] conception of free speech .... [D]issent involves... interaction, appropriation, and transformation.").

107. LEHMAN, supra note 101 , at 80 (emphasis added). The market harm proviso in the white paper's statement is unhelpful because, as the white paper recognizes, courts have protected both actual and potential markets, see id. at 79 , and the fact that a copyright owner seeks payment is evidence that there is some potential market, however high the transaction costs.

108. See Press Release, Houghton Mifflin, Microsoft Joins Authors, Media Companies, First Amendment Advocates, and Others, in Filing a Friend of the Court Brief Supporting Houghton Mifflin (May 16, 2001), available at http://www.houghtonmifflinbooks.com/features/randall_url/ may16pr.shtml; see also PAUL K. SAINT-AMOUR, THE COPYWRIGHTS: INTELLECTUAL PROPERTY AND THE LITERARY IMAGINATION 213 (2003) (reporting that Randall's defenders included "an impressive flotilla of media and technology companies, including the New York Times, the Boston Globe, the Wall Street Journal, the Chicago Tribune, the Los Angeles Times, the Tampa Tribune, Cable News Network, Cox Enterprises, Dow Jones \& Company, and Microsoft" even though "many of the supporting corporations were themselves intellectual property-rich"); Tony Morris, Copyright Could Soon Be Gone with the Wind, TIMES (London), June 12, 2001, Law, at 13 
Microsoft loses very little from having strong fair use protections for transformation-it's not as if someone is going to come out with a critical version of Microsoft Word. ${ }^{109}$ Furthermore, if fair use realigns itself around transformation, Microsoft has much to gain by making the kinds of copying with which it is likely to be faced look much more illegitimate. That is, it's good for Microsoft if an unauthorized copier is either a critic (fair use) or a pirate (infringement), because most copiers won't count as critics.

The condemnation of pure copying that is a natural consequence of the elevation of transformative uses obviously helps content owners against file-trading services and their enemies of long standing, the university and the library. ${ }^{110}$ Thus, courts increasingly find copiers liable even when their aims were educational or research oriented. ${ }^{11}$ If re-visioning fair use as being about transformation is what it takes to keep rights over every pure copy, that's an acceptable price for content owners to pay.

Even better for copyright owners, this re-visioning helps quash a lot of transformative uses too. If The Wind Done Gone is the paradigmatic example of First Amendment-inflected fair use, that means that rewriting without literal copying is the model. Our modern icons, however, tend to take audiovisual form, as Gone with the Wind does, for that matter. If rewriting, redrawing, or reshooting is the ticket to fair use, most people won't be able to afford to ride. ${ }^{112}$ As an extra safeguard against widespread transformative use, we have the Digital Millennium Copyright Act (DMCA), which allows content owners to prohibit any direct copying, even in the course of transforming a work. For example, the recent variants on Star Wars: Episode I-The Phantom Menace, reedited by viewers who, among other things, objected to the Stepin Fetchit-like portrayal of Jar Jar Binks, involved copying the movie's footage almost in its entirety. ${ }^{113}$

(suggesting that media companies were mistaken to side with Randall because a successful fair use defense would weaken their copyright protection).

109. Some software makers have attempted to use contracts to forbid users from criticizing their software. See Robert W. Gomulkiewicz, The License Is the Product: Comments on the Promise of Article $2 B$ for Software and Information Licensing, 13 BERKELEY TECH. L.J. 891, 900 n.51 (1998). Such provisions are likely unenforceable. Most of all, they have nothing to do with transformative use - the software makers are attempting to control speech in other ways, and the availability of transformative use is at best irrelevant to its goals.

110. See, e.g., Linton Weeks, Pat Schroeder's New Chapter: The Former Congresswoman Is Battling for America's Publishers, WASH. POST, Feb. 7, 2001, at Cl (describing the Association of American Publishers's "serious issue" with library lending).

111. See supra note 98.

112. But see Jeremy Egner, Best Bets, Austn AM.-STATESMAN, July 1, 2003, at E2 (discussing Raiders of the Lost Ark: The Adaptation, a shot-for-shot remake of the Steven Spielberg film by boys who began the project at age twelve and finished six years later).

113. See, e.g., Mark Caro, A Night at the Movies Can Take on Many Meanings, CHI. TRIB., Feb. 1, 2004, $\S 7$, at 4 (describing The Phantom Edit); see also Henry Jenkins, Quentin Tarantino's Star Wars? Digital Cinema, Media Convergence, and Participatory Culture, in RETHINKING Media Change: The AEsthetics of TRANSITION 281 (David Thorburn \& Henry 
Without leeway for pure copying, that kind of reworking is automatically illegitimate, and with the DMCA, such reworking may be made technically impossible or at least prohibitively difficult. Because technological measures supported by the DMCA can prevent the intermediate copying necessary for many types of transformative use, the public doesn't even get the benefit of its unequal bargain.

The redefinition of fair use, then, keeps transformative use on the fringes of ordinary uses of copyrighted works. Fair use is for critics, protesters, artists, and other unusual people, just as the First Amendment protects unpopular speakers in other contexts. But the risk is that courts and others may conclude that fair use doesn't protect anything more than the First Amendment requires. Fair use defendants now are well advised to look like traditional First Amendment defendants, little guys condemning those in power. This is perhaps good news for cultural critics, but it makes many traditionally fair uses, such as pure copying carried out for teaching and research purposes, look unfair. ${ }^{114}$

\section{Is It the First Amendment's Fault?}

One could argue that without the First Amendment as a justification for fair use, we would still be seeing the compression of fair use, but we could lose transformative fair uses such as The Wind Done Gone along with traditional pure-copying fair uses. Free speech claims may be the most plausible trump available to opponents of expansive copyright; ${ }^{115}$ in their absence, there might be nothing with which to oppose copyright expansion. ${ }^{116}$ Recent work on the concept of the public domain repeatedly

Jenkins eds., 2003) (discussing the ways in which the distribution of the Star Wars soundtrack, videos, computer games, and other copyrighted works provided the raw material that amateur filmmakers copied and incorporated into their own works).

114. See Matthew D. Bunker, Eroding Fair Use: The "Transformative" Use Doctrine After Campbell, 7 COMM. L. \& POL'Y 1, 2 (2002) (condemning "overprotection of copyright holders at the expense of the free flow of information in nontransformative contexts").

115. Cf. Frederick Schauer, First Amendment Opportunism, in ETERNALLY VIGILANT: FREE SPEECH IN THE MODERN ERA 175 (Lee C. Bollinger \& Geoffrey R. Stone eds., 2002) (discussing the use of First Amendment arguments to defeat other, possibly more logical rights-based claims that lack the First Amendment's persuasive power).

116. For example, Wendy Gordon's powerful argument from Lockean principles for substantial limits on copyright, which "abandons the First Amendment in order to save it," Wendy J. Gordon, A Property Right in Self-Expression: Equality and Individualism in the Natural Law of Intellectual Property, 102 YALE L.J. 1533, 1539 (1993), has unfortunately not had much influence on courts or Congress, especially as compared to her earlier work on market failure as the justification for fair use, Gordon, supra note 102. Perhaps without the First Amendment to fall back on, courts might be more sensitive to claims that particular expansions of copyright law would not "promote the Progress of Science and useful Arts," U.S. CONST. art I, $\S 8, \mathrm{cl} .8$, but such reasoning was mostly absent before First Amendment activists discovered copyright, and I doubt an argument from that Clause would have more success than the more familiar First Amendment claims. 
notes the difficulty of convincing people that the public domain is a place worth preserving, ${ }^{117}$ as against rhetoric that celebrates private ownership. Individualist free speech claims-claims that in a sense reverse the property claim, vesting the fair user with the property-like right to speak ${ }^{118}$ - have instant traction, without need of a public education campaign.

My argument is not that there is some nefarious plot to narrow fair use, but that two concepts are converging, so that it becomes easier to see some uses of copyright law as offending the First Amendment and harder to see what's wrong with others. We have replaced the figure of the creative genius deserving both acclaim and property rights with the figure of another creative genius who deserves her share of the acclaim and the rights because of the new material she's added. ${ }^{119}$ This does nothing to defend copying in itself. The rhetoric of transformative use can then be applied in nontransformative cases to devalue pure copying. As the next Part will show, that is exactly what happened in Eldred, where Justice Ginsburg denigrated First Amendment protection for people who make "other people's speeches." 120

We should be aware of the fair use doctrine that First Amendment reasoning is creating. Free speech claims aren't going to protect against ever-expanding copyright claims unless those who make them also

117. See, e.g., James Boyle, A Politics of Intellectual Property: Environmentalism for the Net?, 47 DUKE L.J. 87 (1997) (arguing for the necessity of a politics of intellectual property); James Boyle, The Second Enclosure Movement and the Construction of the Public Domain, LAW \& CONTEMP. PROBS., Winter/Spring 2003, at 33, 71-73 (arguing that a better theory of the public domain is needed to make its beneficiaries recognize their common interests and organize, as they have not currently done); Mark Rose, Nine-Tenths of the Law: The English Copyright Debates and the Rhetoric of the Public Domain, LAW \& CONTEMP. PROBS., Winter/Spring 2003, at 75, 87 (noting the need for convincing rhetoric in support of the public domain).

118. Cf. Cardtoons, L.C. v. Major League Baseball Players Ass'n, 95 F.3d 959, 976 (10th Cir. 1996) (holding that allowing baseball players to suppress trading cards that parodied them as a violation of their rights of publicity would allow theft of card producer's creative reworkings of players' images).

119. See, e.g., LESSIG, supra note 22, at 10-11, 18-20, 144 (arguing that copyright expansion is most objectionable when it threatens new creativity). Jane Ginsburg, whose pro-ownership views on copyright are often opposed to Lessig's, has recognized that the celebration of transformation inherently elevates the author-genius to a specially deserving status:

Creative users do not disparage authors' rights, though they may initially chafe at them.

Creators have an interest in the copyright system that consumers do not (or, at least, do not acknowledge in the short term).... New creators end up being suborned by the principle of exclusive rights, because they produce works that will be the objects of exclusive rights, too.

Jane C. Ginsburg, Authors and Users in Copyright, 45 J. COPYRIGHT SOC'Y U.S.A. 1, 6 (1997). On the romantic model of authorship generally, see Peter Jaszi, Toward a Theory of Copyright: The Metamorphoses of "Authorship," 1991 DuKE L.J. 455; Peter Jaszi \& Martha Woodmansee, The Ethical Reaches of Authorship, 95 S. ATLANTIC Q. 947 (1996); and Mark A. Lemley, Romantic Authorship and the Rhetoric of Property, 75 TEX. L. REV. 873 (1997) (reviewing JAMES BOYLE, SHAMANS, SOFTWARE, AND SPLEENS: LAW AND THE CONSTRUCTION OF THE INFORMATION SOCIETY (1996)).

120. Eldred v. Ashcroft, 537 U.S. 186, 221 (2003). 
affirmatively argue for the value of access and thus of copying and experiencing works. To take an easy example, public domain advocates' attempts to vaiorize the public domain should focus less exclusively on the value of the creation of new, copyrighted derivative works from public domain materials-such as The League of Extraordinary Gentlemen-and more on the value of the public domain antecedents in themselves-such as Bram Stoker's Dracula and Jules Verne's Twenty Thousand Leagues Under the Sea. ${ }^{121}$ Larry Lessig's support for the Internet Archive and other attempts to copy and preserve as many human creations as possible is an example of the kind of advocacy needed to preserve the resources that enable free speech. ${ }^{122}$ Otherwise, the First Amendment's fair use will be only a rump fair use.

\section{The VAlue of PuRe Copying}

The opinion in Eldred v. Ashcroft relied on fair use to uphold term extension against a First Amendment challenge; at the same time, it treated copiers' interests with indifference. ${ }^{123}$ This Part contests that negative evaluation of copiers. In particular, copying is of value to audiences who have access through copying to otherwise unavailable speech. It also enhances copiers' ability to express themselves; to persuade others; and to participate in cultural, religious, and political institutions.

Precedent made Eldred's First Amendment claims plausible: Copyright is at least a content-neutral speech restriction, ${ }^{124}$ and the Court has generally applied intermediate scrutiny to such restrictions. ${ }^{125}$ They will be upheld if they further an important or substantial governmental interest unrelated to the suppression of free speech, provided the resulting restrictions on speech

121. See, e.g., Sean Piccoli, Strumming to America: A Musical Revival, S. FLA. SUNSENTINEL, Aug. 1, 2003, Showtime, at 28 (discussing The League of Extraordinary Gentlemen and other reworkings of public domain material).

122. See LESSIG, supra note 22, at 108-15; see also Internet Archive, http://www.archive.org (last visited Nov. 24, 2004).

123. 537 U.S. at $218-21$.

124. See, e.g., Baker, supra note 68 , at $922-33$ (citing commentators who argue that copyright is content-neutral, but arguing against that position); $c f$. Eugene Volokh, Freedom of Speech and Intellectual Property: Some Thoughts After Eldred, 44 Liquormart, and Bartnicki, 40 Hous. L. REV. 697, 702, 703-10 (2003) (noting that petitioners' briefs in Eldred took the view that restrictions were content-neutral "for the sake of argument" but arguing that copyright is in fact content based). See generally Neil Weinstock Netanel, Locating Copyright Within the First Amendment Skein, 54 STAN. L. REV. 1, 47-54 (2001) (reviewing arguments for seeing copyright as content based but arguing that copyright is content-neutral because it does not seek to suppress any specific viewpoint or subject matter).

125. See, e.g., Netanel, supra note 124, at 51-53. 
do not burden substantially more speech than is necessary. ${ }^{126}$ Applying this test, Turner Broadcasting System v. FCC upheld government-imposed requirements that cable systems carry a certain number of local broadcast channels. ${ }^{127}$ Although the must-carry requirement burdened cable systems' speech in the sense that it denied them some control over the channels they carried, it served a substantial government interest in preserving free broadcast channels that might otherwise be driven off the air if cable systems refused to carry them. Eric Eldred argued that Turner provided the proper analytical framework for his First Amendment challenge to term extension.

Explaining why intermediate scrutiny was not required, Justice Ginsburg distinguished Turner from Eldred by drawing a line between copiers and real speakers: ${ }^{128}$ "The First Amendment securely protects the freedom to make-or decline to make-one's own speech; it bears less heavily when speakers assert the right to make other people's speeches." 29 As a matter of doctrine, this is false. The New York Times is one of the most securely protected speakers imaginable, even when it prints other people's words on its op-ed pages and in its letters section. ${ }^{130}$ It was not the author of

126. Turner Broad. Sys. v. FCC (Turner II), 520 U.S. 180 (1997). The Supreme Court, years earlier, had remanded the case back to the district court. Turner Broad. Sys. v. FCC (Turner $I$ ), 512 U.S. 622 (1994).

127. Turner II, 520 U.S. 180.

128. In Eldred Justice Ginsburg also distinguished Turner $I$ in another way. She stated that special constitutional concerns arise when the government "compels or burdens the communication of particular facts or ideas." Eldred, 537 U.S. at 221. Presumably, in her analysis, in Turner $I$ the government burdened the cable stations with the facts and ideas contained on the channels cable companies were required to carry. But the government did not select those facts or ideas; the television broadcasters did. If the regulation in Turner I had been as specific as Justice Ginsburg suggested, surely it would have been content based and therefore invalid even by the Turner majority's standards. Copyright does burden a speaker's use of facts or ideas by requiring her to recast them enough to avoid a finding of "substantial similarity" to another work. See Tushnet, supra note 1, at 19-20 \& nn.61-63. Even were that not so, it is the unique value of the expression itself that is lost when copying is prohibited, just as a cable operator ioses some channel capacity to must-carry stations even though it retains many others. The standard adopted by the Turner I Court is supposed to provide moderately speech-protective standards even for content-neutral speech regulations, and to say that copyright doesn't restrict communication of particular facts or ideas is only to say that copyright is content-neutral.

129. Eldred, 537 U.S. at 221; see also Jane C. Ginsburg et al., The Constitutionality of Copyright Term Extension: How Long Is Too Long?, 18 CARDOZO ARTS \& ENT. L.J. 651, 701 (2000) ("The First Amendment is certainly about the freedom to make your own speech. Whether it is about the freedom to make other people's speeches again for them, I have some doubt.").

130. See, e.g., Hurley v. Irish-Am. Gay, Lesbian \& Bisexual Group of Boston, 515 U.S. 557, 570 (1995) ("[T]he presentation of an edited compilation of speech generated by other persons is a staple of most newspapers' opinion pages, which, of course, fall squarely within the core of First Amendment security as does even the simple selection of a paid noncommercial advertisement for inclusion in a daily paper." (citation omitted)); Turner I, 512 U.S. at 675 (O'Connor, J., concurring in part and dissenting in part) ("Selecting which speech to retransmit is, as we know from the example of publishing houses, movie theaters, bookstores, and Reader's Digest, no less communication than is creating the speech in the first place."); Simon \& Schuster v. Members of N.Y. State Crime Victims Bd., 502 U.S. 105, 116 (1991) (holding that both an author and a 
the Pentagon Papers, but that mattered not a whit when the government (which was the author) sought to prohibit publication. ${ }^{131}$ That the New York Times adopts other people's words as its own makes it just like Eric Eldred choosing a public domain work to publish, ${ }^{132}$ or a judge accepting a draft of an opinion by a clerk, or a bookstore selling Ulysses, or a senator quoting the Bible in a debate; the question is precisely what "one's own speech" is. ${ }^{133}$

Imagine that the government, in the name of promoting creativity and deterring imitativeness, banned speakers from copying directly from the public domain. This would be an enormous, intolerable burden on speech, no less so because someone else said the words first, a long time ago. ${ }^{134}$ Justice Ginsburg's statement is at the least impossibly overbroad. Making other people's speeches can be an honorable endeavor, as many a politician would surely attest. First Amendment doctrine should recognize the value of copying, which can be an important part of self-definition and of participation in culture, from singing the national anthem to discussing The West Wing online in exact detail. ${ }^{135}$ The following Sections explore how copying can promote important speech interests, both for the audience and the speakers.

publishing house that selects authors for publication are "speakers" for First Amendment purposes); N.Y. Times Co. v. Sullivan, 376 U.S. 254, 286-88 (1964).

131. See N.Y. Times Co. v. United States, 403 U.S. 713 (1971) (Pentagon Papers case); see also McJohn, supra note 48, at 109. McJohn discussed the Pentagon Papers case, which extended First Amendment protection to a newspaper wishing to reprint government documents, and Bartnicki v. Vopper, 532 U.S. 514 (2001), which held that publication of an illegally recorded phone conversation was protected by the First Amendment. He noted that "originality of speech has never been part of the various tests for evaluating laws that restrict speech." McJohn, supra note 48 , at 109 .

132. Arguably, we need the New York Times to get the speech disseminated, and we don't need Eric Eldred. But this is an empirical question, and the evidence suggests that being in the public domain would make dissemination of at least some works much more likely, particularly where a scholarly or cultural institution is attempting to preserve works with more historical than economic value. See, e.g., Brief of Amici Curiae American Association of Law Libraries et al., Eldred (No. 01-618); Brief of Amici Curiae College Art Association et al., Eldred; Brief of Amici Curiae Hal Roach Studios \& Michael Agee, Eldred; Brief of Amicus Curiae Internet Archive, Eldred.

133. Some of these examples involve consent by the author, while others do not. We may think of the New York Times and the judge as different from Eldred and the senator because the former have an agency-type relationship with the speakers whose words they use and the latter do not (divine inspiration aside). But if one person's words can become another's for First Amendment purposes through some relationship not involving creative composition on the part of the second comer, then creation isn't the only way to create a tie between speaker and speech; the question then is what the other ways should be. It is law that creates the agency-property relationship, not nature. (Indeed, many countries do not treat employees' creations as the copyrighted property of their employers, as the United States does, but rather vest rights in the employees. See generally Ghislain Roussel, The Copyright of Salaried and Employed Authors-a Comparative Study of National Laws, 26 COPYRIGHT 221 (1990)).

134. Cf. Comedy III Prods. v. New Line Cinema, 200 F.3d 593, 595 (9th Cir. 2000) ("[T]he film at issue is in the public domain. We all own it now.").

135. See, e.g., Television Without Pity, http://www.televisionwithoutpity.com (last visited Nov. 24, 2004) (offering detailed recaps of current television shows). 


\section{A. Copying's Value to the Audience}

Audiences benefit from copied as well as original expressions. Eugene Volokh points out that any repetition of his speech is informative to listeners whether delivered by its author or not, because speech's value to consumers "isn't just in its existing somewhere in a bookstore-the value lies in consumers actually hearing or reading it. ... [R]epublished work is materially more valuable to readers than the original that they can't get, that costs too much, or that they don't know about ...."136 Copying promotes democracy by literally putting information in citizens' hands. ${ }^{137}$ When developing countries condemned the dominant international copyright regime as designed to promote the interests of wealthy countries, they appealed to the need to make copies of works for educational and scholarly purposes. ${ }^{138}$ Access to the works, which residents of those countries couldn't afford at copyright owners' prices, was a precondition of any further response to or use of those works. ${ }^{139}$ When Paul Goldstein writes that uses in schools and libraries "advance copyright's general aim of promoting cultural and political discourse, ${ }^{\prime 140}$ he is also invoking the value of access, which can sometimes only be had if the copyright owner's price need not be paid. ${ }^{141}$

Copyright's prohibition on copying can create differential access in precisely the way some First Amendment theorists fear government regulation can subtly distort debate. For example, Who Built America? is an award-winning historical CD-ROM series for high school and college students that uses numerous primary sources. Owners of the sources'

136. Volokh, supra note 124 , at 726.

137. See David Owen, Power to the People: The Photocopier, L.A. TIMES, Aug. 10, 2004, at B13 ("[Photocopying] has given ordinary people a simple means of reproducing and sharing printed information, and, by doing so, it has reduced the ability of the strong to keep secrets from the weak. (Without photocopying, there could have been no Pentagon Papers, for example.) A telling indication of xerography's significance is that in the former Soviet Union, whose rulers maintained their power in part by monopolizing access to information, copiers were guarded more closely than computers, and individual copies were numbered so that they could be traced.").

138. See, e.g., GOLDSTEIN, supra note 11, at 153-54.

139. See also Williams \& Wilkins Co. v. United States, 487 F.2d 1345, 1358 (Ct. Cl. 1973) (holding that copying, for research purposes, material that is "stimulating or helpful," even if not "crucial," produces important social benefits), aff'd by an equally divided Court, 420 U.S. 376 (1975); Julie E. Cohen, Copyright and the Perfect Curve, 53 VAND. L. REV. 1799, 1816 (2000) (noting the connection and potential temporal gap between access and further uses, including transformative uses); Neil Weinstock Netanel, Market Hierarchy and Copyright in Our System of Free Expression, 53 VAND. L. REV. 1879, 1907-09 (2000) (arguing that works shared by many people have additional value over and above the intrinsic value to the individual consumer).

140. GOLDSTEN, supra note 11 , at 208.

141. See also Stephen Jay Gould, Poe's Greatest Hit, NAT. HIST., July 1993, at 10, 15, 18-19 (discussing a book that, without acknowledgement, copied two expensive and inaccessible academic books on mollusks, making their contents inexpensive and available to students in the first half of the nineteenth century). 
copyrights often wanted large payments for use of historically significant works, payments the authors couldn't afford. They substituted federal government and public domain works, altering the way students will understand the past; the materials now overemphasize the federal government's role in Depression-era society and culture. ${ }^{142}$

The access-enhancing benefits of copying are quite similar to the values identified by audience-centered theories of free speech. They show up in Jack Balkin's concept of democratic speech ${ }^{143}$ and to some extent in Owen Fiss's. ${ }^{144}$

The audience's interests in obtaining speech may apply even if we don't think that copying is a valuable activity. As the next Section suggests, however, copying regularly has profound First Amendment value for the copiers themselves.

\section{B. Copying's Value to Speakers}

Pure copying, or copying that is not sufficiently distinct to count as "transformation," serves vital social purposes. I should note that I use the term "copying" to encompass both physically reproducing a work in concrete form-copyright's reproduction right-and singing, playing and otherwise communicating-copyright's performance and distribution rights. Though copyright law distinguishes between reproduction, distribution, and performance rights, its distinctions do not correlate to the ways in which copying as I define it works as free speech.

We tend to divide people into "producers" and "consumers" of copyrighted works and to devalue the act of consumption. Yet what consumption means in this context is reading, watching, listening, and talking about copyrighted works - all valuable expressive activities that can be extremely important to people, both as individuals and as part of a community. ${ }^{145}$ Copying can serve as self-expression, using the most apt words to explain and define beliefs and thoughts; it can assist persuasion, using the best words to reach a particular audience; and it can work as

142. See Brief of Amici Curiae College Art Association et al. at 7, 18, Eldred v. Ashcroft, 537 U.S. 186 (2003) (No. 01-618).

143. See Balkin, supra note 2.

144. See OWEN M. FISS, THE IRONY OF FREE SPEECH (1996) (arguing for a democracypromoting interpretation of the First Amendment, which would allow government to regulate the marketplace of ideas as it regulates economic markets, to correct imbalances of power).

145. See Joseph P. Liu, Copyright Law's Theory of the Consumer, 44 B.C. L. REV. 397, 40620 (2003) (arguing that consumers have interests in autonomy, communication with others, and self-expression that cannot be captured by seeing them either as passive or as new authors). The greatest trick the content industry ever pulled was getting people to believe that readers and listeners are "consumers," as if they swallowed speech like candy. 
affirmation, a way of connecting to a larger group. Many uses serve more than one of those functions.

Not all copying serves First Amendment values, and I am not claiming that it does. I have no free speech right to download entire works for which I could readily pay. But copying is significant to free speech in enough situations that a fair use test that privileges transformation into a new work and discounts pure copying is radically insufficient to protect free speech against copyright's encroachments. Free speech doesn't have to focus on the individual on his soapbox, snarling at the dominant paradigm; it doesn't have to pretend that his words are unique to him. Unfortunately, the reigning model of free speech in First Amendment law is a particular kind of individualism, protecting speakers from government intervention into an otherwise neutral market and assuming that the individual's speech is entirely self-generated rather than assembled from preexisting cultural resources. When that vision gets imported into fair use law, it tends to discount the value of pure copying that promotes access to the means of speech production or enhances participation in a common culture.

My claim here is that pure copying (core copyright infringement, if unauthorized) can also be core First Amendment speech, regardless of the values you think the First Amendment protects. Randall Bezanson argues that adopting other people's speech should be protected by the First Amendment only when it is "sufficiently transformative to support the assertion of intent to speak for oneself and, as importantly, to identify a new expression that justifies calling the First Amendment into play." $146 \mathrm{He}$ values the act of speaking, rather than the artifact of speech. ${ }^{147}$ But someone who copies is speaking, even though the words have been said before. Consider, for example, the meaning of speech to the unconscious copier, who believes herself to be the originator of her words but may still be found to be an infringer. ${ }^{148}$

Bezanson suggests that, absent personal investment in an idea, the act of speaking doesn't represent individual free will or choice: Without requiring transformation of some kind, "no claim by the selector (the person communicating a message, for example) can be made that the speech is his or her own." 149 Yet this characterization seems odd. Both my body and my

146. Randall P. Bezanson, Speaking Through Others' Voices: Authorship, Originality, and Free Speech, 38 WAKE FOREST L. REV. 983, 1056 (2003).

147. See id. at 1067.

148. See, e.g., Herbert Rosenthal Jewelry Corp. v. Kalpakian, 446 F.2d 738, 741 (9th Cir. 1971).

149. Bezanson, supra note 146, at 1069; see also Lionel S. Sobel, Copyright and the First Amendment: A Gathering Storm?, in 19 COPYRIGHT LAW SYMPOSIUM 43, $72-73$ (1971) (arguing that repetition of another's expression serves no First Amendment purpose). Bezanson suggests that certain copying can become First Amendment-protected speech when the copier puts her own credibility or commitments at issue, as when a newspaper implicitily endorses a reporter's claim 
coat are mine, though I didn't make them. Floating underneath seems to be some sort of idea about claiming speech through labor-but then we'd have to decide what sort of labor, presumably including thought-labor, counted. We would probably accept, for example, the proposition that all fifty-six signers of the Declaration of Independence adopted the words as their own-and it was thereby a more powerful document than a collection of fifty-six different explanations of the colonies' plight. ${ }^{150}$ The following Subsections discuss copying as a First Amendment activity, first in furtherance of self-expression, then as a more overtly political, communal act of persuasion and affirmation.

\section{Self-Expression}

Copyrighted works often serve as the self-expression of someone other than the author; they can both feel like the products of the copier's own personality and be perceived by others as such. One of the best-received films at the 2004 Cannes Film Festival, Tarnation, comprised autobiographical home video footage combined with music and video clips. ${ }^{151}$ The director-star used the clips to show the culture that surrounded him and into which he escaped when his home life became too traumatic. ${ }^{152}$ Anne Frank copied a poem to celebrate a friend's birthday, combining it with stickers (possibly copyrighted by someone else) to create a personal tribute. ${ }^{153}$ Teenage girls making home videos to explain their lives play music to show what they value and what they feel. ${ }^{154}$ Putting a song in the

by running his story. Copyright law does not make that distinction, and Bezanson doesn't claim that his theory is consistent with copyright law. See Bezanson, supra note 146, at 1081.

150. Again, Bezanson's argument would encompass signing the Declaration as a transformative act of endorsement, but copyright law wouldn't.

151. See Ian Youngs, Micro-Budget Film Wows Cannes, BBC NEws ONLINE, May 18, 2004, http://news.bbc.co.uk/2/hi/entertainment/3720455.stm.

152. See Pressbook: Tarnation 2-3, 5, 7, available at http://www.wellspring.com/movies/ images/upload/TARNATIONPRESSBOOK.pdf (discussing the film's use of other copyrighted materials to evoke and explain the director's life); see also id. at 11 (explaining that the film "use[d] many of the films and songs that were a part of [the director's] childhood as metaphors for [his] personal experiences and feelings").

153. See David Lange, Reimagining the Public Domain, LAW \& CONTEMP. PROBS., Winter/Spring 2003, at 463, 482 ("'Dear Henny,' Anne Frank wrote ... , 'Pluck roses on earth, and forget me not.' The words are haunting now, poignant, simple, terribly sweet and sad. ... The poet who wrote them was named Snelders. ... Was [Frank] a plagiarist, a pirate, a thief? No decent person would lay such a charge against her memory." (footnote omitted)); see also Nimmer, supra note 93, at 284 (describing the card in greater detail).

154. See Gerry Bloustien, "Ceci N'Est Pas une Jeune Fille": Videocams, Representation, and "Othering" in the Worlds of Teenage Girls, in HOP ON POP: THE POLITICS AND PLEASURES OF POPULAR CUltuRE 162, 173-74 (Henry Jenkins et al. eds., 2002); see also Commercial: Sounds Like First Love (MTV 1999), available at http://www.commercialcloset.org/cgi-bin/iowa/ portrayals.html?record=74 (illustrating the importance of music in ordering and explaining people's 
context of a life reflects on both the music and the life, shaping our understanding of each. Indeed, most Americans can probably recall some song, book, or movie that seemed so perfectly expressive of their own lives that they identified completely with it and would even explain themselves to others by reference to that work. ${ }^{155}$

Symphony patrons debate the merits of one recording of the same piece over another because, although each copies the same musical work, the performances differ in ways both subtle and overt. Recordings can even spark political controversy: Peter Breiner's 1994 arrangement of The StarSpangled Banner, which was used at the Athens Olympics, has been interpreted as a "blue-state" version of the anthem, full of "nuance" and "local variation and possibility" as compared to the traditional arrangements that emphasize "primary colors" and more aggressive music. ${ }^{156}$ Musicians fill concert venues because fans enjoy live performances of the same musical works they can hear at home. ${ }^{157}$ Each new performance produces a different effect on the audience because each one represents the artist's selfexpression; the copy bears the unique marks of its copying.

Musicians cover songs they didn't write, often thereby making their careers. ${ }^{158}$ Some are tributes; some, though generally faithful to the lyrics

lives by featuring a young man making a mix tape of songs about heartbreak after a failed relationship).

155. Cf. John Fiske, $T V$ : Re-Situating the Popular in the People, 1 ConTINUUM: AUSTRALIAN J. MEDIA \& CULTURE n.p. (1987-1988), available at http://wwwmcc.murdoch.edu.au/ReadingRoom/1.2/Fiske.html ("[V]iewers of Crossroads [a British television program] ... were vehement that the program was theirs, it was their cultural capital. And they made it theirs by the pleasures and meanings they produced from it, that articulated their concerns and identities.").

156. Philip Kennicott, Changing Our Tune: Athens Honors American Winners with Kinder, Gentler National Anthem, WASH. POST, Aug. 26, 2004, at C1.

157. See Mark Brown, Bootleg Pirates, ORANGE COUNTY (Cal.) REG., Mar. 19, 1995, at F25 ("All collectors have their own favorite performances that make the compulsion worthwhile.... 'Radio had burned out the regular songs by playing them constantly. I wanted to hear something new and different. After that, I went out of my way to find them,' said [one fan] ...."); Allan Kozinn, Bootlegging as a Public Service: No, This Isn't a Joke, N.Y. TIMES, Oct. 8, 1997, at E2 ("[L]ive recordings . . . capture an electricity that more pristine studio recordings lack. They also let a listener track changes in taste and performance style over the decades and changes in the orchestra's response to different conductors.").

158. See, e.g., Robert Everett-Green, Classics and Beyond, GLOBE \& MAIL (Toronto), Oct. 27, 2001, at R1 (discussing, among others, the Beatles, the Rolling Stones, and Elvis Presley). Karaoke singers perform songs written by others to be part of a group that values singing, even unprofessional singing, and listening as well. See, e.g., Robert Drew, "Anyone Can Do It": Forging a Participatory Culture in Karaoke Bars, in HOP ON POP, supra note 154, at 254. Now, "movieoke" offers movie fans a similar opportunity to act out favorite scenes. See Randy Kennedy, Oughta Be in Pictures? So Just Drink Up!: Amateur Celebrities Pick a Movie and Join In, N.Y. TIMES, Mar. 10, 2004, at E1. A woman who credits herself with inventing the concept had earlier "made a movie short about a kind of cartoon version of herself, a girl whose only way of communicating was speaking movie lines. ... Ms. Fite said [that] movieoke is ... a means to allow people who 'are married to our television sets' and whose personalities are basically a 
and score, operate as commentary on the original simply by virtue of a different performance style. For example, Tori Amos recorded an album of covers of songs about women by men, including Eminem's Bonnie and Clyde '97, in which the singer describes murdering the mother of his child. Both the choice of the song and the delivery convey a message. Amos believed that she could "best express [herself] through other people's words," specifically songs that were already important to the men she consulted. ${ }^{159}$ Only other people's songs could appeal to listeners' preexisting connections with those songs. ${ }^{160}$

Like songs, plays are produced multiple times, because even though they involve wholesale copying of the text, they also offer enormous opportunity for new insights and new emphases-Richard III set during World War I or The Merchant of Venice played in full yuppie costume, for example. ${ }^{161}$ The production of a play clearly involves much creativity, and the director and actors are usually considered as important as the playwright. But the underlying play (like the musical works covered by various performers) is a complete work and, if written sometime in the last eighty years, probably a copyrighted one. Thus, copyright law, even one with only minimal protection for derivative works, must give playwrights some control over full productions of their plays - control that has been exercised, for example, to prevent cross-racial casting of Porgy and Bess ${ }^{162}$ and cross-gender casting of Waiting for Godot. ${ }^{163}$ The variations worked by

pastiche of pop-culture references to get together, drink and put some of that hard-won knowledge to good use." Id.

159. Michael Senft, In the Mood for Tori Amos? Meet 'Strange Little Girls,' ARIz. REPUBLIC, Nov. 18, 2001, at $1 \mathrm{E}$.

160. Id. ("Men often document their emotional lives by music.... When they had a breakup, they had a certain $C D$. When someone died, they had a certain $C D$. When they lost their jobs, they had a certain $C D$. . . If I would have written these songs myself, they wouldn't have had the same impact."); see also Karla Peterson, Pop Talk: Tori Amos, COPLEY NEWs SERVICE, Nov. 26, 2001 n.p. ("“What I wanted to say with this album could only be said by using men's words,' said Amos. ... 'I am as protective of them as I am of my own [songs]' ....").

161. See lawrence W. LeVINe, HighBrow/Lowbrow: THE EMERGEnCE of Cultural HIERARCHY IN AMERICA 16-30, 36-45 (1988) (discussing the use and reuse of Shakespeare as both popular and elite playwright, the prevalence of productions of and quotations from Shakespearean plays in the nineteenth and early twentieth centuries, popular alterations to the plays, and the use of Shakespeare to articulate a specifically American morality). Even evanescent changes in production can make an enormous difference: "[A]n interpretive artist could turn a tragic work into a farce merely by exaggerating the emotional range of his performance or by speaking his lines with an unintended irony." Otto W. Konrad, Note, A Federal Recognition of Performance Art Author Moral Rights, 48 WASH. \& LEE L. REV. 1579, 1588 (1991).

162. See Anthony Tommasini, All-Black Casts for 'Porgy'? That Ain't Necessarily So, N.Y. TIMES, Mar. 20, 2002, at E1.

163. See Leonard Jacobs, German 'Godot' a No Go: Beckett Publisher Quashes CrossGender Production, BACK STAGE, Feb. 6, 2004, at 62. Samuel Beckett was also involved in a lawsuit over a Robert Brustein production of Endgame that substantially changed the set design: "Beckett's empty room reflected [a] sense of desolation. A set suggesting a bombed-out bunker after a nuclear holocaust, by contrast, altered the play's dynamics, for it grounded the individual's 
the director and the cast put an individual stamp on any given production, but they also constitute a single iteration in a chain of copies, gaining meaning in part by reference to the other ways one might stage the same play. ${ }^{164}$ Performances simultaneously involve wholesale copying and wholesale creativity.

People express personal meaning through copying even without performance. Translation is another kind of complete and creative copying. Though translation is mostly confined to the publishing industry because copyright grants translation rights to copyright owners, thousands of fans of Japanese anime add English subtitles to the cartoons and make the subtitled copies available for free on the Internet in order to share their finds with English-speaking viewers. ${ }^{165}$

In theory, performances can be separated from their texts and translations from their sources. Yet as performance and translation involve creative choices, so does reproduction. Personality may also be expressed inseparably from copying. Making mix CDs, discussed above, is not so different from selecting and assembling pieces for anthologies of poetry, articles, letters from a historical figure, or other collections. Those things all require the exercise of judgment and creativity and can be quite socially beneficial; they also inform us about the commitments of the editors and compilers. ${ }^{166}$ Although we may wish to distinguish between "pure" copying

despair in an external event that was shared by all." MARTIN GARBUS WITH STANLEY COHEN, TOUGH TALK: HOW I FOUGHT FOR WRITERS, COMICS, BIGOTS, AND THE AMERICAN WAY 192 (1998). Otto Konrad discusses Beckett's Endgame and other instances in which performances, though faithful to the underlying script or score, were perceived by authors as travesties. See Konrad, supra note 161, at 1580 . Further afield, a recent alternate soundtrack to the film Harry Potter and the Sorcerer's Stone was designed to be played while watching the original movie but alters the characters' relationships. It attempts to create an experience closer to the oral tradition, in which each storyteller put a unique spin on a standard story; the artist who created the soundtrack noted that " "whenever anybody does a production of [a play], it's fair game' to turn tragedy into farce or slapstick into melancholy, simply by devising new line readings or stage directions." Daniel Radosh, Harry Potter: The Digital Remix, SALON, June 22, 2004, http://archive.salon.com/ent/feature/2004/06/22/harry.

164. I am indebted to Francesca Coppa for these insights. See also Marvin Carlson, Theatrical Performance: Illustration, Translation, Fulfillment, or Supplement?, 37 THEATRE J. 5 (1985) (discussing theories of performance as altering a play, for better or worse, and concluding that performances and plays are both necessarily incomplete); Konrad, supra note 161 , at 1602 (noting that works intended to be performed are both self-contained and in need of an interpreter).

165. See Christopher Palmeri \& Nanette Byrnes, A Tsunami of Japanese Pop Culture, BUSINESSWEEK ONLINE, July 26, 2004, http://www.businessweek.com/magazine/content/ 04_30/b3893094.htm (quoting an expert who describes "fansubbing" groups as "cottage cultural intermediar[ies]").

166. See Sony Music Entm't v. Does 1-40, 326 F. Supp. 2d 556, 564 (S.D.N.Y 2004) ("“T] file sharer may be expressing himself or herself through the music selected and made available to others."); Lloyd L. Weinreb, Fair's Fair: A Comment on the Fair Use Doctrine, 103 HARV. L. REV. 1137,1143 n.29 (1990); cf. Marilyn Randall, PragmatiC Plagiarism: AUTHorship, PROFIT, AND POWER 211 (2001) (discussing defenders of Martin Luther King, Jr.'s copying who argue that King's originality lay in his selection and arrangement of material); infra notes 184-186 
and distribution, such as handing out Bible tracts in the street, and copying that incorporates creative input, editing, or interpretation, the line between the two is often blurred. Selection of what to copy is an editorial, interpretive task, as Tori Amos's work and the contents of newspaper letters columns testify. The proselytizer, after all, has to choose a particular version of the Bible, and the Bible over the Bhagavad Gita. ${ }^{167}$ In other areas, copyright law recognizes that selection and arrangement can be highly creative, valuable activities even if the editor does not add content of her own. The editor possesses a copyright in her selection and arrangement as a "collective work" (at least if she has the right to use her selections). ${ }^{168}$ Copying becomes a creative, expressive act.

Even a single selection can have expressive power. Consider the Clinton-Gore campaign's adoption of the 1977 Fleetwood Mac song Don't Stop (Thinking About Tomorrow) ${ }^{169}$ as its theme song, following a long tradition of appropriating popular songs to distill and promote a campaign theme. Truman's theme I'm Just Wild About Harry was revived from the 1920s; Eisenhower's I Like Ike was taken from Irving Berlin's hit They Like Ike from the 1950 musical Call Me Madam; Johnson's Hello, Lyndon was a version of Hello, Dolly; George H.W. Bush's theme was This Land Is Your Land, written by Woody Guthrie in $1940 .{ }^{170}$ Even when supporters sing

and accompanying text (discussing King's copying). A recent article describes many CD burners' attitudes toward their creations:

Most users of music file-sharing services do not copy the products for sale by the music industry. While the industry sells albums, artificially shaped to the capacities of their commercial format, $\mathrm{LP}$ or $\mathrm{CD}$, file-sharers tend to rip songs.

As their favorite musicians recombine digital samples to create new music, downloaders recombine digital songs in new contexts.

"I don't think they think of it as copying music," said Joe Levy, deputy managing editor of Rolling Stone. "It's a very individual experience for them. They want the songs they want in the order they want. Then it becomes not the new Mary J. Blige album, but their own mix. It's a much more individual package of music. Kids view it as an interactive and creative act."

Betsy Frank, the executive vice president for research and planning at MTV Networks, who studies young TV and music audiences, said the people in her focus groups tended to describe copying as an assertive act, a way of navigating a media environment that bombards them with information ....

Leland, supra note 72.

167. I thank Neil Netanel for pressing me on this point.

168. See 17 U.S.C. $\$ 101$ (2000) (defining "collective work").

169. See FleETwoOd MAC, Don't Stop, on RUMOURS (Warner Bros. Records 1977). Christine McVie, who wrote the song, intended a different meaning than the Clinton-Gore campaign espoused, yet the song proved perfectly effective when recontextualized into a political statement.

170. See OsCaR BRAND, PRESIDENTIAL CAMPaign SONGS: 1789-1996 (Smithsonian Folkways 1999). 
specially created songs, they are using expression created by others to demonstrate their own, powerfully held sentiments. ${ }^{171}$

Or consider that Chief Justice Rehnquist, dissenting in Texas $v$. Johnson, could think of no more eloquent way to argue for the value of the American flag than by quoting John Greenleaf Whittier's poem Barbara Frietchie, among other sources whose reproduction added power to his argument. ${ }^{172}$ Likewise, reprints of W.H. Auden's poem September 1, 1939 filled a deep need in many people to explain their feelings about September $11,2001 .{ }^{173} \mathrm{We}$ recite poetry because it seems to us to express profound truths that could not be better expressed-could not even be expressed at all-with other words. ${ }^{174}$

This recontextualization is not transformative in a way that copyright could ever recognize, but that does not mean that the meaning of the copied work is static. ${ }^{175}$ Many copyright scholars have promoted the idea that there is no such thing as originality, in the sense of authorship without debt to other works. The flip side is that there is no such thing as an identical copy. ${ }^{176}$ The difference between two copies of Ulysses is, of course, not the same as the difference between Ulysses and The Odyssey. Nonetheless, our

171. See Fran Wood, John Kerry, Can You Name That Tune?, STAR-Ledger (Newark), July 25, 2004, Perspective, at 3; Stuart Schimler, Singing to the Oval Office: A Written History of the Political Campaign Song (Feb. 13, 2002), http://www.presidentelect.org/art_schimler_ singing.html.

172. 491 U.S. 397, 424-25 (1989) (Rehnquist, C.J., dissenting).

173. Stephen Burt, "September 1, 1939" Revisited: Or, Poetry, Politics, and the Idea of the Public, 15 AM. LITERARY HIST. 533, 534-35 (2003); see also Volokh, supra note 124, at 726-27 (discussing other core political speech that requires copying expression).

174. Cf. Gordon, supra note 116 , at 1569 ("Some poems, some ideas, some works of art, become 'part of me' in such a way that if I cannot use them, I feel I am cut off from part of myself." (footnote omitted)). Gordon is most interested in people who create new, transformative works in response to existing works, see id. at 1556, whereas I am arguing that endorsing and adopting existing works is itself an important part of self-definition and, therefore, selfexpression. But see Rubenfeld, supra note 2, at 34 (suggesting that reading poetry is generally not self-forming).

175. See WALTER BENJAMIN, The Work of Art in the Age of Mechanical Reproduction, in IllumINATIONS 211, 214 (Hannah Arendt ed. \& Harry Zohn trans., Fontana Press 1992) (1955) (arguing that all reproduction transforms the copied work because "it enables the original to meet the beholder halfway," as when a public choral production plays in a private living room); JOHN BERGER ET AL., WAYS OF SEEING 29 (1972) (explaining that context inevitably changes meaning); TERRY EAGLETON, LITERARY THEORY: AN INTRODUCTION 11 (2d ed. 1996) ("All literary works... are 'rewritten[,'] if only unconsciously, by the societies which read them; indeed there is no reading of a work which is not also a 're-writing[.']"); supra note 97.

176. One need only look at the reader reviews on Amazon.com to see that people often seem to be reading very different books with the same text. The uniqueness of texts for readers is quite literal in modem times, when we rarely huddle around a book together; we read our own, individual copies or watch programs on our own TVs. Cf. Fiske, supra note 155 (noting that researchers have found multiple contradictory interpretations of the TV show Dallas in different groups). 
recognition that poems are made out of other poems ${ }^{177}$ should be balanced by the recognition that no woman reads the same poem twice, because even if it's the same poem, she's not the same woman. ${ }^{178}$

\section{Persuasion}

Sometimes people copy not because someone else's words suit them but because the words suit the situation. They copy instrumentally, to produce a desired result, which is usually that the audience agree with the speaker. "Boilerplate" in a news report or a social worker's case report may thus be perfectly acceptable; new forms of expression might even get in the way of communicating the relevant information. As Russell Hunt points out, unlike academics, the authors of most texts "aren't in a position where the main point of the text is to demonstrate their own expertise; the point is to generate a text that gets done what needs to get done." 179 When words are tools, the speaker's creativity may be less important than her words' suitability for the task at hand.

Copying may be useful to provide the right words for the job; it may also be useful to provide the right source. David McGowan's recent article on why the First Amendment cannot provide much guidance for copyright law is itself an example of copying that is valuable because the copied speech is valuable. ${ }^{180}$ In the course of arguing that copying is worth less than writing one's own words, McGowan quotes and relies heavily on a word-by-word analysis of one of Justice Brandeis's more famous opinions. ${ }^{181}$ This isn't just irony. McGowan has reason to think that Brandeis's words, familiar to readers and invested with Brandeis's nearly century-old legal reputation, are likely to be more persuasive than McGowan's own words filling the same amount of space. ${ }^{182}$ Moreover, the

177. See NORTHROP FRYE, Ethical Criticism: Theory of Symbols, in ANATOMY OF CRITICISM: FOUR ESSAYS 71, 97 (Princeton Univ. Press 2000) (1957) ("Poetry can only be made out of other poems; novels out of other novels.").

178. See VIRGINIA WOOLF, The Modern Essay, in THE COMMON READER 267, 276 (1925) ("Life wells up and alters and adds. Even things in a book-case change if they are alive; we find ourselves wanting to meet them again; we find them altered.").

179. Russ Hunt, Two Cheers for Plagiarism, INKSHED, Autumn 2003, at 10,15, available at http://www.stthomasu.ca/inkshed/nletta03/hunt.htm.

180. David McGowan, Why the First Amendment Cannot Dictate Copyright Policy, 65 U. PITT. L. REV. 281 (2004).

181. See id. at 323-24 (quoting 142 words from Whitney v. Califormia, 274 U.S. 357, 375 (1927) (Brandeis, J., concurring)).

182. McGowan would probably point out that he has made substantial contributions to the work in interpreting Brandeis and in making many points of his own, which is certainly true. Yet the value of his work wouldn't be the same if it had a Brandeis-shaped hole in it; the copying provides argumentative weight and grounds his argument in a tradition of constitutional interpretation. See id. at 323-26. But cf. id. at 329 (arguing that derivative works created by copiers lack any First Amendment value that couldn't be achieved without copying and that 
subject of McGowan's copying, a judicial opinion, is itself a work whose authority is constituted by repetition. Much more than poems are made out of other poems, cases are made out of other cases. At the same time, copying may increase the authority of the copied work, making the fact of copying part of the reason a work is persuasive. ${ }^{183}$

The history of one famous speech further illustrates the limited relevance of originality. On August 28, 1963, at the Lincoln Memorial, in front of 250,000 marchers (and with millions of others watching on television), Martin Luther King, Jr. delivered what we now know as the I Have a Dream speech. The vivid expression in the speech was unique neither to King nor to that particular speech. He and others had said the same things before, often in the same words or nearly exact paraphrase. ${ }^{184}$

derivative authors remain "free to distribute their own work, without whatever they have copied" under the current copyright system).

183. See, e.g., Consumers Union of the United States v. Gen. Signal Corp., 724 F.2d 1044, 1050 n.6 (2d Cir. 1983) (holding that the defendant could reprint Consumers Union's positive review of its vacuum cleaner and characterizing the defendant as "saying that it believes that the viewing public places great stock in what Consumer Reports has to say" and that "[i]n this way, the use of such statements and the credit given to Consumer Reports actually may reinforce a positive public perception of the magazine" (emphasis altered)). Jack Balkin and Sandy Levinson, themselves quoting extensively, explain this phenomenon well in the context of legal scholarship:

As Barbara Herrnstein Smith has noted, "the repeated inclusion of a particular work in anthologies" or "its frequent citation or quotation by professors [and] scholars" is more than a simple repetition. It is a "recommendation of value" that "not only promotes but goes some distance toward creating the value of that work." Citations and quotations not only draw attention to works, they make works the kinds of works that attention is paid to and hence should be paid to. "[B]y making the work more likely to be experienced at all," citations and quotations "make it more likely to be experienced as valuable."

J.M. Balkin \& Sanford Levinson, How To Win Cites and Influence People, 71 CHI.-KENT L. REV. $843,844-45$ (1996) (alterations in original) (footnotes omitted); see also RALPH WALDO EMERSON, Quotation and Originality, in LETTERS AND SOCIAL AIMS 155, 1.73 (Boston, James R. Osgood \& Co. 1876), available at http://www.emersoncentral.com/quotations.htm ("[A] writer appears to more advantage in the pages of another book than in his own. In his own, he waits as a candidate for your approbation; in another's, he is a lawgiver."); MARJORIE GARBER, QUOTATION MARKS 19-20 (2003) (discussing the ways in which quotation creates authority for the original speaker and the second speaker); RANDALL, supra note 166, at 211 (same).

184. For discussion of King's earlier use of the same language, see DREW D. HANSEN, THE DREAM: MARTIN LUTHER KING, JR., AND THE SPEECH THAT INSPIRED A NATION 70, 109-13, $118,171-73$ (2003). $C f$. id. at 171 ("[S]everal important NAACP figures had heard King many times before, and so, to them, his speech at the march sounded like any other King address."). The speech twice quoted the Bible, see id. at 103, and borrowed other biblical language, see id. at 10102, 119-20. It also quoted the Declaration of Independence, see id. at 53, 58, the song America, see id. at 61, and the spiritual Free at Last, see id. at 62 . King drew on other sources, as well. See $i d$. at 108-09; id. at 115 ("King was always quick to pick up an apt turn of phrase or line of oratory and adapt it for use in his own speeches."). King made some changes in wording: For example, he changed another preacher's "Green Mountains and the White Mountains of Vermont and New Hampshire" to the "prodigious hilltops of New Hampshire." See id. at 109 (internal quotation marks omitted). But the changes most likely would be insufficient to save him from charges of copyright infringement. See, e.g., Wildlife Express Corp. v. Carol Wright Sales, 18 F.3d 502, 511 (7th Cir. 1994) (noting that substantial similarity, not identical copying, is the test for copyright infringement). For additional instances of King's use of others' words in his sermons and other 
What was historically significant was that huge numbers of people in the audience had never heard him preach. ${ }^{185}$ For them, that he was copying was irrelevant to the power of his words. It didn't matter that the expression wasn't original; it did matter that it was King speaking, at that time, at that place, to those people. Keith Miller argues that King's copying helped promote his agenda of racial justice, by drawing on familiar words that reassured white listeners: "King skillfully inserted his arguments against segregation into a web of ideas and phrases that moderate and liberal white Protestants had already approved. .. . Using words his listeners had already heard, he reinforced what they already believed."186

The subsequent appropriation of I Have a Dream also illustrates the way quotation in a new context can change, even reverse, meanings. King's line about wanting his children to be judged not by the color of their skin but by the content of their character was appropriated by affirmative action opponents. ${ }^{187}$ The King estate argued that a Republican ad incorporating a clip of King delivering those lines was infringement and succeeded in having the ad pulled from the air. ${ }^{188}$ In that case, it was important to opponents of affirmative action to use both the powerful rhetoric and the attribution to King as a civil rights hero; it was significant to the persuasive power of the ad that they were quoting King. ${ }^{189}$

works, see KeITH D. Miller, VoICE OF DeliveranCE: THE LANGUAGE OF MARTIN LUTHER KING, JR. AND ITS SOURCES 3-7, 15-16, 55, 70, 72-73, 75, 78-80, 88-91, 100-01, 107-08, 120-21, 191-93 (1992). King apparently thought his practices were perfectly acceptable, making no attempt to hide his borrowing and copying from well-known sources. See id. at 135-36.

Oscar Wilde was also prone to self-plagiarism. His most famous speech, made from the dock after his conviction for sodomy, was actually a patchwork of earlier, lesser-known speeches. See Francesca Coppa, Performance Theory and Performativity, in PALGRAVE ADVANCES IN OSCAR WILDE STUDIES (Frederick S. Rosen ed., forthcoming 2004) (manuscript at 72, 87-88, on file with author). Many other examples of public figures finding the right words and sticking with them could doubtless be found.

185. See HANSEN, supra note 184 , at $99-100$ ("King's speech at the march was so powerful in part because it exposed a national audience, for the first time, to his genius as a preacher .... The March on Washington simply provided a national audience with its first opportunity to witness a pulpit performance that those active in the civil rights movement could see many times a year.").

186. MILLER, supra note 184, at 85, 195-96 (describing how King became inextricably linked with his borrowed words and thus a powerful symbol against injustice of all kinds); see also id. at 192 ("King's listeners retained his ideas and phrases more easily because the familiar strains of his sermons made them more memorable... . Had he instead supplied sermons with profoundly original content, he would never have legitimized his radical tactic of civil disobedience and his radical goals of ending racism, poverty, and war.").

187. Dave Lesher, GOP Pulls King Segment from TV Ad for Prop. 209, L.A. TIMES, Oct. 25, 1996 , at A26.

188. See MILLER, supra note 184 , at 223 . The King estate litigates aggressively to control dissemination of excerpts of the I Have a Dream speech. See, e.g., Estate of King v. CBS, 194 F.3d 1211 (11 th Cir. 1999); Martin Luther King, Jr. Ctr. for Soc. Change v. Am. Heritage Prods., 508 F. Supp. 854 (N.D. Ga. 1981), rev'd, 694 F.2d 674 (11 th Cir. 1983).

189. Cf. City of Ladue v. Gilleo, 512 U.S. 43, 56 (1994) ("[T]he identity of the speaker is an important component of many attempts to persuade. A sign advocating 'Peace in the Gulf' in the 
King's writings also generated some controversy when scholars announced that, in some cases, large portions of his scholarly work were copied without attribution from other sources. Although King's practices deviated from norms of scholarship, others have pointed out that such copying was ordinary in the homiletic tradition of preaching from which he came. ${ }^{190}$ Certain stories, parables, and biblical explications were time tested and religiously effective, whereas originality might not have produced the necessary worship effect. ${ }^{191}$ By adopting earlier work, King gained authority as the embodiment of a respected tradition. ${ }^{192}$

In fact, King's practices demonstrate the value to individuals of being able to use the words they think most appropriate. ${ }^{193}$ Whatever we think about King's failure to cite and attribute in the academic context, we would

front lawn of a retired general or decorated war veteran may provoke a different reaction than the same sign in a 10-year-old child's bedroom window . . ." (footnote omitted)). Just as King is linked to his speech regardless of who originally came up with the turns of phrase, it is not Theodore Sorensen but John F. Kennedy who is indelibly associated in the public mind with famous lines such as "Ask not what your country can do for you-ask what you can do for your country." Text of Kennedy's Inaugural Outlining Policies on World Peace and Freedom, N.Y. TIMES, Jan. 21, 1961, at A8. Sorensen wrote the words, but Kennedy made them powerful and is commonly regarded as their source. Thomas Mallon believes Sorensen plagiarized the phrase from Oliver Wendell Holmes, Jr., who wrote, "It is now the moment... to recall what our country has done for each of us, and to ask ourselves what we can do for our country in return." THOMAS MALLON, STOLEN WORDS: FORAYS INTO THE ORIGINS AND RAVAGES OF PLAGIARISM 130 (1989). Sorensen's phrasing, however, seems so far superior, tightening the chiasmus, that it serves as another example of borrowing that improves upon the source.

190. See MILLER, supra note 184 , at 25-26, 125-28, 191.

191. See id. at 127. Ministers count eloquence as successful only when it saves souls, and originality ranks lower still:

After all, how many truly original sermons are possible on Luke's account of Christ's birth ...?

Moreover, the alternative to borrowing is not always wondrous.... [S]ome ministers are entirely capable of preaching homilies that are highly original, yet perfectly dreadful.

$\ldots$

... If a sermon inspires a deeper faith and better living, it succeeds; if not, it fails. Nothing else matters.

Id.

192. See id. at 137 ("For King and others, borrowing sermons ... served as a way of arguing from authority. By lauding certain preachers, the Protestant community had in effect placed upon their sermons its Good Housekeeping Seal of Approval. When King reiterated their texts, he evoked the authority of those certified by all of liberal Protestantism.").

William Alford's account of classical Chinese attitudes toward copying invokes similar themes: Copying showed respect for the wisdom of the past, demonstrated knowledge and judgment, and preserved general access to the state's heritage. See WILliam P. ALFORD, TO STEAL a Book Is an Elegant Offense: INTEllectual Property LAW IN ChINESE CIVILIZATION 25-29 (1995).

193. See S.F. Arts \& Athletics v. U.S. Olympic Comm., 483 U.S. 522, 569 (1987) (Brennan, J., dissenting) (comparing the rhetorical power of Paul Cohen's war protest slogan "Fuck the Draft" with one reading "I Strongly Resent the Draft"); Cohen v. California, 403 U.S. 15, 26 (1971) ("[W]e cannot indulge the facile assumption that one can forbid particular words without also running a substantial risk of suppressing ideas in the process."). 
be hard pressed to disagree with his assessment of the value of the words he copied. Some speech lacks a substitute.

For more ordinary citizens, copying can also be a means of persuasion. David Thelen's study of how ordinary citizens responded to the Iran-Contra affair relies on hundreds of letters written to Representative Lee Hamilton, the chair of the joint congressional committee investigating the scandal. Many communicated with Congress using others' words, often whole newspaper articles, "underlined, highlighted, starred, [with] exclamation points, [or] arrows." "194 "The thoughts were the writers', but the words were often those of wordsmiths that they expected would more effectively persuade the likes of congressmen." 195 Likewise, advocacy groups promoting letter-writing campaigns to politicians often suggest a specific text or even provide preprinted postcards so that a citizen need only fill in her name. In such cases, copying is a political tool, used to produce particular results. ${ }^{196}$ Originality does not matter-indeed, it might be counterproductive when the aim is to sound authoritative- to the resulting democratic dialogue.

\section{Affirmation}

Just as copying can serve to persuade, it can make a copier part of something larger. ${ }^{197}$ For example, to many Americans, reciting the Pledge

194. DAVID THELEN, BECOMING CITIZENS IN THE AGE OF TELEVISION 112 (1996); $c f$. GARBER, supra note 183, at 21-22 ("We are as much informed of a writer's genius by what he selects as by what he originates. We read the quotation with his eyes, and find a new and fervent sense; as a passage from one of the poets, well recited, borrows new interest from the rendering. As the journals say, "the italics are ours.""' (quoting EMERSON, supra note 183, at 172)).

195. THELEN, supra note 194, at 112. Many letter writers explicitly indicated that newspaper columns and other materials expressed their thoughts better than they could themselves. See id.; see also id. at 114 ("Writers drew on [Bible quotes, lines from popular songs, poems, or folk expressions], not to demonstrate erudition-for they rarely cited chapter, verse, or page, or worried about the original or accurate form of the quotation-but because the sentiment seemed to distill the wisdom of ages."); $c f$. RANDALL, supra note 166 , at 36 ("[R]epetition is the means by which non-authors-scribes, imitators, compilers-participate in eternal truth by facilitating its transmission.").

196. See, e.g., Am. Library Ass'n, Action Alert: Protect the Balance in Copyright Law, http://congress.nw.dc.us/ala/mail/oneclick_compose/?alertid=6670186 (last visited Nov. 24, 2004) (suggesting that citizens cut and paste given text into a message to their congressional representatives). The point is not to impress with new rhetoric, but to convince someone to take action.

197. A brief aside on negation, the opposite of affirmation. Sometimes copying serves to criticize rather than laud-most notably as "appropriation" art, which mocks popular culture and challenges conventional notions of art, value, and originality. See Amy M. Adler, Note, PostModern Art and the Death of Obscenity Law, 99 YALE L.J. 1359, 1366-67 (1990); E. Kenly Ames, Note, Beyond Rogers v. Koons: A Fair Use Standard for Appropriation, 93 CoLUM. L. REV. 1473 (1993). Because others have argued for reassessment of fair use standards for appropriation artists and because my concern is with more usual kinds of copying, I will not discuss appropriation art or other forms of explicitly critical copying in any detail. But $c f$. Gordon, 
of Allegiance-with or without a reference to God-is (or can be) a profoundly political act, important because of the repetition of a precise series of words.

Affirmation, like persuasion, is a type of self-expression, but it is unlike the usual image of self-expression because it consists of subordinating uniqueness to conform with a group. Nonetheless, individual freedom is freedom to endorse and agree-freedom to copy-along with freedom to dissent. A Republican who agrees with her party's positions is engaging in core political speech when she repeats them, notwithstanding that her words sound just like other Republicans'. Repetition confirms membership to herself and to the world around her. ${ }^{198}$

More than just a product of individual choice, however, repetition has extra value, both intrinsic and instrumental, that comes from public association with like-minded souls. As discussed above, the Declaration of Independence drew power from being the statement of a body of men rather than the work of a single pen. "We mutually pledge to each other our lives, our fortunes, and our sacred honor": The words are performative, creating a bond by stating shared principles, announcing to the world that this group stands together.

First Amendment doctrine has generally upheld this value under the rubric of freedom of association. Recognizing that shared opinions are easier to maintain than those held in isolation, the Supreme Court has declared that freedom of association is "especially important in preserving political and cultural diversity and in shielding dissident expression." 199 People who do not hear their opinions reflected in others' speech may well be pressured into silence. The connection to copying is that the right of a group of people to advocate a consistent message presupposes a repeated message, like the oath all Boy Scouts must take. ${ }^{200}$ First Amendment jurisprudence has recognized that a group has a "voice" that may be heard when individual voices would be ignored; the metaphor suggests a voice composed of many voices, all singing the same song. ${ }^{201}$

supra note 116 , at 1568 (noting that copying may be necessary in order to criticize or contest a religious interpretation). The existence of appropriation art is further evidence that copying is not necessarily unthinking, unconditional, or uncritical. My argument is that this can be true even when the copying comes from love rather than contempt.

198. Establishment Clause jurisprudence is, in fact, crucially concerned with the associational effects of copying - the message sent when one party (a government entity) adopts the speech of another (a religious group). See County of Allegheny v. ACLU, 492 U.S. 573, 600-01 (1989) ("[T]he very concept of 'endorsement' conveys the sense of promoting someone else's message. ... [T] The Establishment Clause prohibits ... the government's lending its support to the communication of a religious organization's religious message.").

199. Roberts v. U.S. Jaycees, 468 U.S. $609,622(1984)$

200. See Boy Scouts of Am. v. Dale, 530 U.S. 640, 649 (2000).

201. See, e.g., FEC v. Nat'l Conservative Political Action Comm., 470 U.S. 480, 494-95 (1985) (noting that political action committees, by aggregating contributions, "amplif[y] the voice 
Religion, like patriotism, often requires exact replication of sacred texts. As David Nimmer observed in discussing the Dead Sea Scrolls, "When the precise wording of a text is at stake, ... to paraphrase is heresy." 202 Worldwide Church of God v. Philadelphia Church of God, for example, involved a splinter sect that made copies of a religious text that the mother church had disavowed. ${ }^{203}$ Because the mother church owned the copyright in the text, the court enjoined the splinter sect from copying what its members believed to be the true words of God and from sharing those words with other people. ${ }^{204}$ Worldwide Church of God provides an example of copying at the core of self-definition, in this case self-definition through religious expression. ${ }^{205}$

In modern times, proselytization (spreading the words of a prophet) can easily involve copyrighted works. A religion's core texts may still be within copyright, as Scientology's are. Christian teenagers even defend file sharing of religious music as a method of spreading the Word, likening music to the Bible itself, which should be disseminated by any means necessary. ${ }^{206}$

Nor are God and country the only motivations for copying as affirmation. A number of people celebrate June 16, Bloomsday, with James Joyce-related activities, including (at least before the copyright holder objected) public readings of Ulysses. ${ }^{207}$ The online LiveJournal community

of their adherents" and that donations allow contributors to "add their voices" to the group's message (alteration in original) (internal quotation marks omitted)); Minn. State Bd. for Cmty. Colls. v. Knight, 465 U.S. 271, 309 (1984) (Stevens, J., dissenting) (arguing that joining together to speak with one voice may be the only way to "make[] the right to express one's views meaningful"); Citizens Against Rent Control/Coal. for Fair Hous. v. City of Berkeley, 454 U.S. 290, 294 (1981) (noting that banding together can make views known when individual voices "would be faint or lost").

202. David Nimmer, Copyright in the Dead Sea Scrolls: Authorship and Originality, 38 Hous. L. REV. 1, 136 (2001) (internal quotation marks omitted); see also DAVID NIMMER, COPYRIGHT: SACRED TEXT, TECHNOLOGY, AND THE DMCA 227-28 (2003) ("[T]he Torah commands of the king that he personally write a copy of sacred scriptures. . . The king, emblematic of the people as a whole, must discharge the sacred task of copying the Torah wordfor-word."); Thomas F. Cotter, Gutenberg's Legacy: Copyright, Censorship, and Religious Pluralism, 91 CAL. L. REv. 323, 359-62 (2003) (arguing that the exact words of religious texts, like those of secular laws, may be crucial to adherence to religious law).

203. 227 F.3d 1110 (9th Cir. 2000).

204. Id. at 1121 .

205. Though, like many affirmations, this one was made in the face of opposition, the members of the splinter church believed that their religion required them to share a text that copyright law said they could not disseminate. They copied to agree with the source, not to condemn it.

206. See Katharine Mieszkowski, Thou Shalt Not Steal, SALON, May 25, 2004, http://archive.salon.com/tech/feature/2004/05/25/christian_pirates/index.html ("For some Christian kids ... sharing the religious hits that express their faith is their way of spreading the word. 'They wanted it to be part of their ministry. They wanted to share some of the positive messages from their music with non-believers. It's an evangelistic impulse." (quoting David Kinnaman)).

207. In 2000 , Stephen Joyce, trustee of the Joyce estate, took legal action against public readings of Joyce's works, and he recently warned the Irish government and arts institutions that 
provides another example of copying as literal badge of identity. LiveJournal members use one or more "icons" to signify themselves and their commitments, usually pictures, usually copied from other sources. The content of the copied picture serves to identify the LiveJournal member with a group that shares her interest, producing identification in the sense of both defining a unique personality and linking the user with the image she uses. ${ }^{208}$

One recent case about copyright in model legal codes provides an even more fundamental challenge to the idea that the first person to arrange words in a particular order has the strongest claim to them. In Veeck v. Southern Building Code Congress International, the en banc Fifth Circuit ruled that once a model code written by a private organization had been adopted into some jurisdiction's positive law, others were free to copy the law despite the private group's copyright claims. ${ }^{209}$ The majority explained its rationale several different ways, reasoning that there can be no copyright in the law that governs us and that, as law, the code became a fact. ${ }^{210}$ The majority's most breathtaking claim was, however, that the adoption of the code as law by the legislature, as representatives of the people, made the people the relevant authors. ${ }^{211}$ Their adoption had consequences the original code writing didn't-it put the coercive power of the state behind the words - and that was a relevant sort of authorship. Adoption was the most powerful kind of endorsement possible.

\footnotetext{
"any failure to clear the use of material under the copyright of the estate" would result in a lawsuit, thus preventing public readings on the centennial of Bloomsday. See Tara Pepper, Portrait of the Daughter: Two Works Seek To Reclaim the Legacy of Lucia Joyce, NEWSWEEK INT'L, Mar. 8, 2004, at 67, available at http://msnbc.msn.com/id/4408820; Jamie Smyth, Joyce Estate Warns Festival over Copyright Issues, IRISH TIMES, Feb. 9, 2004, at 3.

208. See Alek Tarkowski, Petri Dishes, 100px x 100px: User Pictures on LiveJournal and Associated Cultural Practices: Version 1.0: An Initial Exploration, http://terminal.n17.waw.pl/stable/ pliki/petri_dishes.html (last edited Mar. 12, 2004) ("In fandom communities users often use images of celebrities or characters in a manner that blurs the distinction between signifying that is iconic (of the celebrity) and symbolic (of the user)."); Alek Tarkowski, Petri Dishes, 100px x 100px: User Pictures on LiveJournal and Associated Cultural Practises: Version 2.0: A Further Exploration of the Phenomenon 21, http://terminal.n17.waw.pl/stable/pliki/petri_dishes_2.pdf (last visited Nov. 24, 2004) (" $[F]$ andom sometimes expresses its interests and allegiances through simple multiplication of content, without any transformations, by using them as user pictures."). Trademarks (many of which are also protected by copyright) often function in similar ways to announce a user's commitments to himself, to others like him, and to the world. See Rosemary J. Coombe, Critical Cultural Legal Studies, 10 Yale J.L. \& HUMAN. 463 (1998); Rochelle Cooper Dreyfuss, We Are Symbols and Inhabit Symbols, So Should We Be Paying Rent? Deconstructing the Lanham Act and Rights of Publicity, 20 COLUM.-VLA J.L. \& ARTS 123 (1996); Jessica Litman, Breakfast with Batman: The Public Interest in the Advertising Age, 108 Y ALE L.J. 1717 (1999).
}

209. 293 F.3d 791 (5th Cir. 2002) (en banc).

210. See id. at 795-96, 800-01.

211. See id. at 799; see also Bldg. Officials \& Code Admin. v. Code Tech., 628 F.2d 730, 734 (1st Cir. 1980) (reversing grant of preliminary injunction and noting that "citizens are the authors of the law, and therefore its owners" regardless of who drafted the law); THOMAS HobBes, Leviathan 112 (Richard Tuck ed., Cambridge Univ. Press rev. student ed. 1996) (1651) (referring to an "author" as one who has "authority" to act). 


\section{Copyright's Real-World Suppressive Effects}

Maybe the situation isn't as bad as all that. Maybe we can call many of the uses I've discussed either de minimis or transformative and thus noninfringing. In that case, no one has to worry that mere quotation will be deemed illegal. Even setting aside the many instances of full-scale copying discussed above as instances of free speech, however, both case law and experience counsel against the assumption that most casual copying is too trivial to copyright owners to be suppressed. The suppression may be direct, or it may be the result of a chilling effect caused by legal uncertainty. Either way, copyright interferes with piecemeal quotation and reuse as well as with wholesale copying.

De minimis uses do exist; ${ }^{212}$ they're just not the way to bet. Where sound recordings are at issue, for example, courts have found sampling brief excerpts for use in other recordings to be infringement or potential infringement, ${ }^{213}$ and record companies now require artists to obtain permission for any sample. ${ }^{214}$ One court has even found that unrecognizable, de minimis sampling of a sound recording infringes the copyright owner's absolute right against any physical reproduction of protected material. ${ }^{215}$ While the situation is worst in music, a television company was found to be an infringer for showing portions of a poster in the background of a scene for a total of 26.75 seconds over the course of one episode of the half-hour sitcom Roc. ${ }^{216}$ As the poster case illustrates, the de minimis defense is especially unlikely to protect copying of images, which are often useless if not reproduced in full or nearly so. ${ }^{217}$

212. See, e.g., Newton v. Diamond, 349 F.3d 591 (9th Cir. 2003) (holding that copying a sequence of three notes from a musical composition was de minimis because the average audience would not recognize the appropriation). Such cases do not show that the doctrine of de minimis copying offers substantial protection for copiers. Not only did copying three notes suffice to buy the copier a lawsuit, but the equally brief sample from the sound recording containing the musical composition was licensed, because the record company would not rely on a de minimis defense for a sound recording. See id. at 593. Under current law, one copyright covers the words and music, while a separate copyright covers each recording of the musical work, so two copyrights are potentially involved in each sample. 1991).

213. See, e.g., Grand Upright Music v. Warner Bros. Records, 780 F. Supp. 182 (S.D.N.Y.

214. See Howard Siegel et al., Music Publishing, in 2 COUNSEling CliENTS IN THE ENTERTAINMENT INDUSTRY 1999, at 323, 379 (PLI Intellectual Prop., Course Handbook Series No. G-554, 1999); see also Michael P. McCready, The Law Regarding Sampling, http://www.music-law.com/sampling.html (last visited Nov. 24, 2004) ("When you sample someone's song without permission, it is an instant copyright violation... One note from a sound recording is a copyright violation.").

215. See Bridgeport Music v. Dimension Films, No. 02-6521, 2004 WL 1960167 (6th Cir. Sept. 7, 2004).

216. See Ringgold v. Black Entm't Television, 126 F.3d 70, 73 (2d Cir. 1997).

217. See Mattel v. Walking Mountain Prods., 353 F.3d 792, 804 (9th Cir. 2003) (suggesting that, while songs, video, and written works "are naturally severable," visual works may require 
Even where copying only reproduces small portions of a work, however, the current definition of de minimis copying would not apply to most of the uses described above, because those uses often depend on the recognition of quotation, and "a taking is considered de minimis only if it is so meager and fragmentary that the average audience would not recognize the appropriation., ${ }^{218}$ As a result, a recognizable use is not going to be de minimis. It may still have some chance as a fair use, but even fair use is inadequate to protect much partial copying. Current doctrine generally refuses to recognize noncritical recontextualization as fair use. ${ }^{219}$ The sound recording sampling cases and the coursepack photocopying cases, which involve copying portions of books and articles and joining them with other excerpts, are the most obvious examples. ${ }^{220}$ Likewise, one court wrote that using the Louis Armstrong classic What a Wonderful World to contrast with scenes of violence and pain requires licensing, because that use just comments on the negative aspects of the world portrayed rather than commenting on the song itself. ${ }^{221}$

It should be no surprise that publishers thus require permission for even brief quotations, resolving the legal uncertainty with a bright-line rule that affords security by rigidly controlling speech. Stephen King's author's note to Christine states rather plaintively that "[g]etting the necessary legal permissions to use lyrics is hard work,",222 hard work that was done forty-six

wholesale reproduction in order to comment on them); Ty, Inc. v. Publ'ns Int'l, 292 F.3d 512, 522 (7th Cir. 2002) (pointing out that copying part of a picture of a Beanie Baby would be useless in a guide to Beanie Babies); Ames, supra note 197, at 1483-84.

218. Fisher v. Dees, 794 F.2d 432, 435 n.2 (9th Cir. 1986). This result occurs because de minimis copying is defined as the absence of substantial similarity, which itself exists when "an average lay observer would recognize the alleged copy as having been appropriated from the copyrighted work." Ideal Toy Corp. v. Fab-Lu Ltd., 360 F.2d 1021, 1022 (2d Cir. 1966).

219. See supra note 97 . Sometimes excerpting transforms works, and sometimes it doesn't. Compare Hofheinz v. AMC Prods., 147 F. Supp. 2d 127 (E.D.N.Y. 2001) (holding that use of brief film clips in documentaries was transformative fair use), aff'd, No. 01-7060, 2002 U.S. App. LEXIS 13562 (2d Cir. May 20, 2002), with Elvis Presley Enters. v. Passport Video, 349 F.3d 622 (9th Cir. 2003) (holding that use of brief video and audio clips was not fair use), amended, 3.57 F.3d 896 (9th Cir.), cert. denied, 124 S. Ct. 2886 (2004), and cases cited supra note 98.

220. See cases cited supra note 98.

221. Abilene Music v. Sony Music Entm't, 320 F. Supp. 2d 84, 92 (S.D.N.Y. 2003) (discussing Terry Gilliam's 12 Monkeys and Barry Levinson's Good Morning, Vietnam, in which the song is used in this ironic way).

222. STEPHEN KING, CHRISTINE, at author's note (1983). The amicus brief of the College Art Association in Eldred $v$. Ashcroft describes the rigors of the permission process for academics; the costs in time and money are often substantial if not prohibitive. See Brief of Amici Curiae College Art Association et al. at 6-10, Eldred v. Ashcroft, 537 U.S. 186 (2003) (No. 01-618); see also Promoting Technology and Education: Turbo-Charging the School Buses on the Information Highway: Hearing Before the Senate Comm. on the Judiciary, 107th Cong. 19 (2001) (prepared statement of Geraid A. Heeger, President, Univ. of Md. Univ. Coll.) (describing a university cinema program that spent $\$ 600,000$ on a failed attempt to develop a distance education course ("Negotiations [to use five- to thirty-second film clips] went on interminably.... Some people never responded, others demand a great deal of money, some simply said no.")); Youngs, supra 
times for that book, including permission to use quotes such as "Tach it up, tach it up / Buddy, gonna shut you down",223 and "Take you for a ride in my car-car" (repeated several times). ${ }^{224} \mathrm{King}$, whose work chronicles the details of late-twentieth-century life and whose characters listen to the radio, watch television, and often think in terms of the popular (copyrighted) culture they know well, usually gets multiple permissions for each novel, often for similarly abbreviated quotes. ${ }^{225}$ Most high school yearbooks contain many more quotations than King's work, and if they were as readily available to copyright owners as King's novels-if, for example, they were available online-it would take a brave attorney to advise a school board to keep quotations up against a copyright owner's protest. ${ }^{226}$

In such a case, the school would have less of a commitment to the copied material than the student who had chosen it and a greater incentive to avoid litigation because its pockets would be relatively deeper and its image less sympathetic than that of a poor student. Indeed, any time there is an intermediary such as a publisher or an Internet service provider (ISP), pure copying may easily be controlled and suppressed, even when the copying is minimal and the profit potential is low. To get their films distributed, directors of documentaries must get permission for every song fragment or piece of art appearing momentarily in the background of a scene. ${ }^{227}$ Correspondingly, publishers generally now require permission for almost any copying, even in academic contexts, especially when images are

note 151 (describing a film with a budget of $\$ 218$ for production and $\$ 400,000$ for copyright clearance of the song and video clips it borrowed).

223. KING, supra note 222, at 168.

224. Id. at 203.

225. See, e.g., STEPHEN KING, DREAMCATCHER 621 (2001) (seven permissions); STEPHEN KING, IT (1986) (thirty-one); STEPHEN KING, MISERY (1987) (eight); STEPHEN KING, ROSE MADDER (1995) (seven); STEPHEN KING, SALEM'S LOT 293 (1975) (four, including permission to quote one line-nine words-from Bob Dylan's North County Blues ("Tell you now that the whole town is empty.")); STEPHEN KING, THE STAND (complete \& uncut ed. 1990) (ten); see also William F. Patry \& Richard A. Posner, Fair Use and Statutory Reform in the Wake of Eldred, 92 CAL. L. REV. (forthcoming Dec. 2004) (manuscript at 18, on file with author) ("In Margaret Atwood's recent novel Oryx and Crake, the author thanks 'John Calder Publications and Grove Atlantic for permission to quote eight words from Samuel Beckett's novel, Mercier and Camier.' Eight words? Please." (footnote omitted)). But see STEPHEN KING, FIRESTARTER, at epigraph (1980) (not showing permission for "It was a pleasure to burn," from Ray Bradbury's Fahrenheit $451)$.

226. Cf. School Settles CD Flap, DJ ZONE: DJ NewS SouRCE, May 17, 2004, http://www.djzone.net/pg/news/wire/school-settles-cd-flap.shtml (discussing souvenir CDs produced for a high school prom, which got the prom committee in trouble with a major music label for including three of the label's songs, though ultimately the label granted a retroactive license).

227. See, e.g., William M. Landes \& Richard A. Posner, THE ECONOMIC STRUCTURE of INTELLECTUAL PROPERTY LAW $216 \mathrm{n} .16$ (2003) (criticizing interpretations of the law that require permissions for minimal use); LESSIG, supra note 22, at 95-99; Lawrence Lessig, Innovating Copyright, 20 CARDOZO ARTS \& ENT. L.J. 61 1, 612-14 (2002). 
involved. ${ }^{228}$ Most film journals, for example, will not publish even a single frame of film without permission. ${ }^{229}$ The problem affects both those who come to bury copyrighted works and those who come to praise them: Numerous scholars have been denied permission to quote or reprint pictures on the basis of copyright owners' disagreement with their interpretations, and fair use is no help to such scholars if publishers refuse to rely on the uncertain doctrine. ${ }^{230}$ Publishers and distributors rationally fear copyright owners' threats, especially when they can publish an inoffensive book or article instead of one that would require risking a fair use defense. ${ }^{231}$ Copyright owners' aggressive stances make the situation worse. Owners often assert that any copying by anyone, however minimal, requires permission, and many would-be users lack the resources to challenge these ownership claims. ${ }^{232}$ These structural features of publishing and distribution are unlikely to change any time soon.

In addition, it is worth emphasizing that quoting in new contexts isn't independently creative. The idea of transformation tends to make us focus on what has been added, presuming that the new material is what is valuable, when in many cases it is the mixture that matters. Grace Kelly's

228. See, e.g., FREE EXPRESSION POL'Y PROJECT, "THE PROGRESS OF SCIENCE AND USEFUL ARTS": WhY COPYRIGHT TODAY THREATENS INTELLECTUAL FREEDOM 16 (2d ed., rev. \& updated 2003), available at http://fepproject.org/policyreports/copyright2d.pdf; Patry \& Posner, supra note 225 (manuscript at 16-19).

229. See Brief of Amici Curiae College Art Association et al. at 13, Eldred v. Ashcroft, 537 U.S. 186 (2003) (No. 01-618).

230. See id. at 8; see also The Copyright Term Extension Act of 1995: Hearing on S. 483 Before the Senate Comm. on the Judiciary, 104th Cong. 83 n.8 (1995) (prepared statement of Dennis S. Karjala) (noting press reports that the estate of songwriter Lorenz Hart refuses permission to quote Hart's lyrics to any biographer who mentions Hart's homosexuality); THE MANY LIVES OF THE BATMAN: CRITICAL APPROACHES TO THE SUPERHERO AND HIS MEDIA, at vi (Roberta E. Pearson \& William Uricchio eds., 1991) ("DC Comics refused to grant us the right to use images as they did not feel that this book was consistent with their vision of the Batman."). Fair use is especially unhelpful for those who wish to comment on visual images, where usually one needs to use all or most of an image, meaning that one of the fair use factors is an automatic strike against the use. See Brief of Amici Curiae College Art Association et al. at $12 \mathrm{n} .8$; see also id. at 13-14 ("CAA members... repeatedly report that rights issues are so murky that no publisher will take the risk of relying on fair use of images of artwork."); id. at 14 (stating that one publisher of books about film and television refuses to use any photograph without permission).

231. See Brief of Amici Curiae College Art Association et al. at 14.

232. See, e.g., Patry \& Posner, supra note 225 (manuscript at 16) ("The Copyright Society of the U.S.A. advises on its website that the copying even of just a few seconds of a movie or a television program is not fair use: '[i]f film clips or photographs from motion pictures, television programs, or other sources are used, consent is required from the copyright owner to use clips or photographs in a motion picture, no matter de minimis or short." (alteration in original)); id. (manuscript at 17-18) ("Recently the New York Review of Books published a newly discovered notebook entry by Virginia Woolf, and a note at the end of the article states: 'Copyright $(\mathcal{2} 2003$ by the Estate of Virginia Woolf. No part of this text may be reproduced without the express prior consent of Hesperus Press.' . . . The note is pure bluff, but a public-domain publisher threatened by a lawyer representing Hesperus Press with legal action would think twice about publishing even the briefest passage without consent." (footnotes omitted)). 
role was added to Cornell Woolrich's story It Had To Be Murder to create Rear Window, but collecting all of Grace Kelly's bits from the movie wouldn't create a work that could stand on its own, and the parts would mean something different and less than before. ${ }^{233}$ The copied and the new elements are both vital, and the value added is not independent of the value appropriated.

One could restate the objection that I am overly pessimistic in the following way: Regardless of what copyright doctrine says and what traditional publishers do, most copying by ordinary people is beneath copyright owners' notice. Even if they could protest to schools and ISPs, they rarely do, and thus copyright law poses no real obstacle to this type of free speech. Yet there's something problematic about a defense of a law that relies on massive underenforcement to protect speech, in part because random, infrequent enforcement can too easily become discriminatory enforcement. Moreover, enforceability changes, both through technological means such as copy protection and through broader societal shifts to monitorable media such as the Internet. Nor should citizens who want to comply with the law be deterred from speaking because they believe that the letter of the law prohibits any recognizable copying.

\section{CODA: SOME SPECULATION ABOUT COPYRIGHT'S EFFECTS ON THE FIRST AMENDMENT}

Transformation as free speech is based on an individualist, dissentprotecting model of the First Amendment. Moreover, this model presumes that the context of speech is irrelevant, so that identical words have identical meaning regardless of who says thern or where they're said. It presumes that only critics need and deserve to build on preexisting materials to be able to speak the truth. It presumes that identification with another's words is not as valuable or authentic as disagreement. This Essay has attempted to contest all these presumptions.

The effect of bringing the First Amendment to copyright through the mechanism of transformative fair use is that the property rights of the copyright owner are limited only to make way for a second individual rightsholder, the second-coming creator. ${ }^{234}$ Individual authorship remains the focus. While transformative use addresses some obvious free speech problems with copyright law, its very prominence may end up obscuring

233. See Stewart v. Abend, 495 U.S. 207, 238 (1990) (holding that unauthorized use of Woolrich's story was unfair even if it only constituted a small part of the motion picture); Weinreb, supra note 166, at 1144 \& n.34 (discussing how the film was "transformative" yet not a fair use according to accepted doctrine).

234. See supra note 110 and accompanying text. 
the basic speech-promoting structure of copyright law to the detriment of free speech more generally. A better approach would be to understand fair use as part of an overall system designed to generate speech, which requires varied tactics.

Courts should recognize that various kinds of copying, not united by some overall theory about creating new works, promote freedom of speech. The statutory limits, such as the limited term and provisions allowing educational and nonprofit copying, should also be recognized as vital to the protection of free speech. Although courts may be unable to create the detailed exceptions and limits that Congress has, they can interpret those statutory provisions with an eye toward their speech-enhancing purposes. The point is not to denigrate fair use, but to recognize that many kinds of uses of copyrighted material may be justified, not just uses that put a critical spin on a prior work.

\section{CONCLUSION}

My purpose in this Essay has been largely critical: identifying a conflict between basic principles of copyright law and basic First Amendment goals. It is natural to hope for a solution, some way to reconcile the contending interests. Unfortunately I have no such solution to offer. Instead, I briefly outline and assess possibilities for ameliorating the copyright/First Amendment clash. Extended discussion is beyond the scope of this Essay; my aim is rather to show that the conflicts will likely remain intractable. Two plausible fixes suggest themselves: revamping fair use, or giving up and finding a new way to provide copyright's speech-promoting incentives. A less restrictive alternative to current copyright law, for example, would be a form of compulsory licensing that allows anyone to copy anything as long as the copyright owner receives some payment, perhaps managed by a collective licensing group like ASCAP. ${ }^{235}$

Fixing fair use is obviously the less radical alternative to ending copyright's exclusive rights. We could tinker with the elements in the standard fair use test, in particular the purpose of the use and the amount used. First, the law might exempt noncommercial or at least small-scale noncommercial copying (private use) along with transformative uses.

235. See generally WILLIAM W. FISHER III, PROMISES TO KEEP: TECHNOLOGY, LAW AND THE FUTURE OF ENTERTAINMENT 199-258 (2004), available at http://cyber.law.harvard.edu/ people/tfisher/PTKChapter6.pdf; Netanel, supra note 2; Neil Weinstock Netanel, Impose a Noncommercial Use Levy To Allow Free Peer-to-Peer File Sharing, 17 HARV. J.L. \& TECH. 1 (2003) (offering a proposal, somewhat more restricted than Fisher's, that would privilege only noncommercial uses related to peer-to-peer file sharing); Digital Media Project, Alternative Compensation System Scenario, http://cyber.law.harvard.edu/media/scenario4 (last visited Nov. 24, 2004). 
Transformative fair use would be treated as an instance of a larger principle, that of protecting the free speech functions of self-expression, persuasion, and affirmation. Instead of one prototypical fair use-The Wind Done Gone-we could have several, including the scholar at the photocopier and the fan in the chat room. ${ }^{236}$ Second, the law might limit what counts as sufficient copying to constitute reproduction or creation of a derivative work, so that activities such as sampling and quoting would clearly be noninfringing.

Requiring complete or near-complete copying to find infringement would be most helpful with literary works and least helpful with visual works, which often need to be shown in full for "quotation" to be effective. ${ }^{237}$ Short films, such as the Zapruder film and the recording of Rodney King's beating, would also often need to be reproduced nearly in full to be useful. ${ }^{238}$ Likewise, as discussed in Part III, full-scale copying ${ }^{239}$ of copyrighted works such as plays and music often has substantial speech value, because the complete copyrighted work interacts with performers' and directors' inputs, and pervasive copying may be necessary to convey a persuasive message or to participate in a group's activities. ${ }^{240}$ Even setting aside complete copying, there is no way to know in advance how much copying is too much. A judicial attitude of tolerance toward copying that is not quantitatively large would help when fair use cases were actually litigated, but any standard would be difficult to codify and would still subject many uses to a chilling uncertainty. ${ }^{241}$ In sum, allowing partial copying would still leave problems with many significant activities. ${ }^{242}$

236. Cf. Bunker, supra note 114, at 16-17 (arguing against dominance of transformation); Lape, supra note 98, at 722-24 (same); Weinreb, supra note 166, at 1140-41 (arguing that fair use should not be distilled into a limited set of definite principles but should allow multiple factspecific kinds of use).

237. See supra notes $217,229-233$ and accompanying text.

238. Cf. L.A. News Serv. v. KCAL-TV Channel 9, 108 F.3d 1119, 1123 (9th Cir. 1997) (holding that copying clips of the Reginald Denny beating was not fair use).

239. Here again I use "copying" to encompass both reproduction and performance. See supra text accompanying note 145 .

240. We could say that the additional creativity involved in performing justifies limiting playwrights' and composers' rights more than movie directors', but that solution seems oddly discriminatory in favor of nonparticipatory media. And then, of course, "movieoke" and mash-ups of popular songs also involve both wholesale reproduction and performance along with additional creative content, just like plays.

241. Other related problems would arise in defining what a complete "work" was-is copying a single film still, for example, copying an entire work? Copyright law recognizes that characters can be copyrighted. See, e.g., MGM v. Am. Honda Motor Co., 900 F. Supp. 1287, 1293 (C.D. Cal. 1995). Is a Harry Potter t-shirt with Harry, Hermione, and Ron then a copy of three works? Cf. Jenkins, supra note 113, at 301-03 (discussing amateur Star Wars films made with multiple separate action figures).

242. Though less likely than judicial change, expanded statutory exemptions for educational and private nontransformative copying could also help in some situations. Although statutory exemptions are inflexible, they provide predictability for activities falling within their scope. See 
Nor would exempting small-scale noncommercial uses be a perfect solution. Free speech interests in copying still exist when the copying is large scale or commercial, such as a copy shop producing academic coursepacks, the New York Times reprinting the Pentagon Papers, or even the file-sharing activities of a person who truly believes that everyone would be better off if they listened to the wisdom of her favorite band. Finally, fixing fair use would exchange false positives (findings of infringement when free speech is on the side of fair use) for false negatives (findings of fair use when free speech is not involved and when allowing copying only does harm to the incentive to produce new works). Although I have given short shrift to copyright's incentive function in this Essay in order to focus on the values served by copying, I still believe that a copyright law with reasonably broad protections is a good idea.

The second major option solves the collision between copyright and free speech by wiping out standard copyright law, trading exclusive rights for a right to profit from uses of copyrighted works through compulsory (or negotiated) industrywide licensing. At least there would be no barrier posed by a particular entity's refusal to license a particular use. The only barrier to copying would come from insufficient funds. No one need be restrained from speaking by the prospect that a court will disagree with a fair use claim. Yet poor people also have interests in self-expression and persuasion. One might think that freedom of speech is a way to preserve political and social equality in the face of wealth disparities, but if wealth controlled access to foundational elements of speech, that protection would no longer exist.

Compulsory licensing has many defenders and detractors as a solution to copyright's conundrums. ${ }^{243}$ In my opinion, the most disturbing thing about large-scale compulsory licensing is that it eliminates unfair uses by eliminating fair uses and gets rid of infringement by getting rid of

supra note 105 and accompanying text; see also Michael L. Baroni, A Pirate's Palette: The Dilemmas of Digital Sound Sampling and a Proposed Compulsory License Solution, 11 U. MIAMI ENT. \& SPORTS L. REV. 65, 94-95, 98-99 (1993) (discussing benefits of predictability in welldefined statutory licenses); Ann Bartow, Educational Fair Use in Copyright: Reclaiming the Right To Photocopy Freely, 60 U. PITT. L. REV. 149, 224-25 (1998) (suggesting legislative expansion of exemptions to make educational copying easier and safer); Carol M. Silberberg, Preserving Educational Fair Use in the Twenty-First Century, 74 S. CAL. L. REV. 617, 636-39 (2001) (discussing benefits of current safe harbors for classroom photocopying).

243. Along with Fisher, Lessig, and Netanel, see sources cited supra notes 2, 67, 235, numerous other scholars have considered the virtues and demerits of compulsory licensing. See, e.g., T. GALLAGHER, COPYRIGHT COMPULSORY LICENSING AND INCENTIVES (Oxford Intellectual Prop. Research Ctr., Working Paper No. 2, 2001), available at http://www.oiprc.ox.ac.uk/ EJWP0201.pdf (supporting compulsory licenses on efficiency grounds); Jane C. Ginsburg, Copyright and Control over New Technologies of Dissemination, 101 COLUM. L. REV. 1613, 1642-45 (2001) (describing problems with existing compulsory licenses); Robert P. Merges, Contracting into Liability Rules: Intellectual Property Rights and Collective Rights Organizations, 84 CAL. L. REV. 1293, 1308-16 (1996) (criticizing compulsory licensing regimes). 
noninfringing acts. Everybody pays for everything, including playing a CD privately ${ }^{244}$ and quoting from a book, which were never before part of the copyright owner's rights. ${ }^{245}$ Indeed, such proposals raise the possibility of potentially infinite demands for compensation. Why stop at quotation? Why not add in payment for discussion, or for inspiration?

These proposals-particularly the first, of expanding fair use in several directions-have the virtue of being thinkable, if unlikely, departures from the current system. Nonetheless, these options offer only a choice of awkward and imprecise mechanisms for reconciling free speech with copyright. The fundamental problem is that the concerns of copyright, though they relate to the production and circulation of speech, are orthogonal to those of free speech, and neither one can be resized to fit the other. The problems of managing personal use in an impersonal world have only increased the gap between copyright's categories and those of the First Amendment.

Yet something must be done when litigants invoke the First Amendment in a copyright case. Denied a presence in the main body of copyright law, the First Amendment returns as fair use. This back-door approach has several troublesome effects. It obscures the speech-enhancing role of other-especially statutory-limits on copyright that the judiciary could likely never impose, allowing those limits to be dissolved in favor of copyright owners. It narrows fair use to the most offensive, antagonistic uses of a copyrighted work, ignoring the values served by copying in the service of agreement and enlightenment. It distorts the communal, reciprocal nature of copyright's theory of free speech, a theory that is attentive to the ways in which the speech of some structures the speech of others.

Fair use and free speech are messy concepts. They serve different ends at different times. We should struggle against the impulse to tell only one story about how they work and how copyright interacts with the First Amendment. Sometimes a copy is just a copy; other times it is vitally important speech.

244. See, e.g., FISHER, supra note 235 , at 199-258 (suggesting that compensation would be tied to how often a recording was played).

245. The details of the proposals vary: We could impose a levy on digital storage and transmission paid by each user regardless of whether she was actually copying. Netanel addresses concerns posed by such cross-subsidization, see Netanel, supra note 235 , at $67-74$, though in my opinion the problems associated with a pay-for-all-uses regime would still remain. 